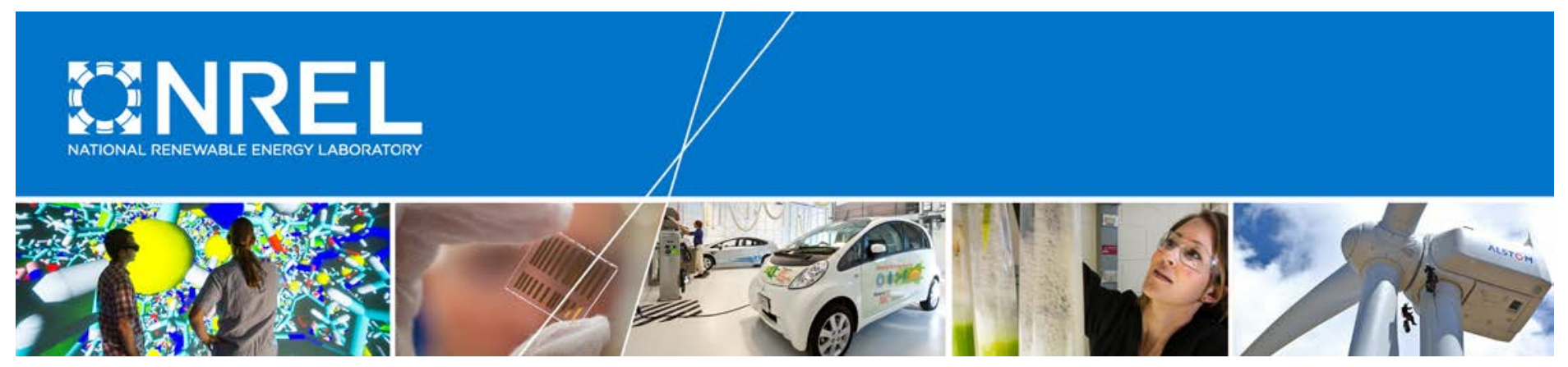

\title{
Preliminary Assessment of Spatial Competition in the Market for E85: Presentation Supplement
}

Bentley Clinton, Caley Johnson, Kristi Moriarty, Emily Newes, and Laura Vimmerstedt National Renewable Energy Laboratory

NREL is a national laboratory of the U.S. Department of Energy Office of Energy Efficiency \& Renewable Energy Operated by the Alliance for Sustainable Energy, LLC

This report is available at no cost from the National Renewable Energy Laboratory (NREL) at www.nrel.gov/publications.

Technical Report

NREL/TP-6A20-66943

February 2017 


\section{Preliminary Assessment of Spatial Competition in the Market for E85: Presentation Supplement}

Bentley Clinton, Caley Johnson, Kristi Moriarty, Emily Newes, and Laura Vimmerstedt

National Renewable Energy Laboratory

Prepared under Task No. SA15.0500
National Renewable Energy Laboratory 15013 Denver West Parkway Golden, CO 80401

303-275-3000 • www.nrel.gov
NREL is a national laboratory of the U.S. Department of Energy Office of Energy Efficiency \& Renewable Energy Operated by the Alliance for Sustainable Energy, LLC

This report is available at no cost from the National Renewable Energy Laboratory (NREL) at www.nrel.gov/publications.

\section{Technical Report}

NREL/TP-6A20-66943

February 2017

Contract No. DE-AC36-08GO28308 


\section{NOTICE}

This report was prepared as an account of work sponsored by an agency of the United States government. Neither the United States government nor any agency thereof, nor any of their employees, makes any warranty, express or implied, or assumes any legal liability or responsibility for the accuracy, completeness, or usefulness of any information, apparatus, product, or process disclosed, or represents that its use would not infringe privately owned rights. Reference herein to any specific commercial product, process, or service by trade name, trademark, manufacturer, or otherwise does not necessarily constitute or imply its endorsement, recommendation, or favoring by the United States government or any agency thereof. The views and opinions of authors expressed herein do not necessarily state or reflect those of the United States government or any agency thereof.

This report is available at no cost from the National Renewable Energy Laboratory (NREL) at www.nrel.gov/publications.

Available electronically at SciTech Connect http:/www.osti.gov/scitech

Available for a processing fee to U.S. Department of Energy and its contractors, in paper, from:

U.S. Department of Energy

Office of Scientific and Technical Information

P.O. Box 62

Oak Ridge, TN 37831-0062

OSTI http://www.osti.gov

Phone: 865.576.8401

Fax: 865.576.5728

Email: reports@osti.gov

Available for sale to the public, in paper, from:

U.S. Department of Commerce

National Technical Information Service

5301 Shawnee Road

Alexandria, VA 22312

NTIS http://www.ntis.gov

Phone: 800.553 .6847 or 703.605 .6000

Fax: 703.605.6900

Email: orders@ntis.gov 


\section{Preface}

This report complements a presentation separately published by the National Renewable Energy Laboratory titled, Preliminary Assessment of Spatial Competition in the Market for E85, which is available at http://www.nrel.gov/docs/fy17osti/67603.pdf. The report provides clarification and background information for the associated presentation. In addition, the appendix to the report includes supporting figures, a technical discussion, and detailed results tables.

Ben Clinton was the lead analyst for the work presented in this report, and he is its lead author. He performed the analysis while a doctoral candidate at the University of Colorado Boulder and in the Research Participant Program at the National Renewable Energy Laboratory (NREL). Contributing authors, all of the NREL, and their roles include:

- Kristi Moriarty: industry perspectives, dispensing station technology, and connections to data sources

- Caley Johnson: industry perspectives and connections to data sources

- Emily Newes: data analysis strategies

- Laura Vimmerstedt: client relations, project concept, and editing. 


\section{Acknowledgments}

The authors are grateful for the helpful comments offered by John Cabaniss, Michael Elchinger, Daniel Kaffine, Kara Podkaminer, Daniel Steinberg, as well as participants in related presentations at the University of Colorado Boulder and at the 2016 annual meeting of the Northeast Agricultural and Resource Economics Association. Special thanks to Mike Meshek for editing. 


\section{Selected Definitions}

\section{E85}

Flex-fuel vehicle (FFV)

High-blend ethanol fuels

Spatial competition

Rack prices

Retail prices

Renewable identification number (RIN)
A fuel mixture composed of $51 \%-83 \%$ ethanol by volume. Exact ethanol percentages vary based on location and time of year.

Source: http://www.afdc.energy.gov/fuels/ethanol_e85.html

A type of vehicle designed to use fuels containing up to $85 \%$ ethanol.

Source: https://www.fueleconomy.gov/feg/flextech.shtml

An alternative term for E85. In contrast to low-blend fuels (e.g., E10 and E15, which are blends of up to $10 \%$ and $10.5 \%-15 \%$ ethanol, respectively).

Source: http://www.afdc.energy.gov/fuels/ethanol_blends.htm 1

Firm behavior based on proximity to, or density of, competing firms.

Fuel prices at the distribution terminal. Retail station owners often purchase fuels for retail sale at these distribution terminals. Rack prices do not include transportation costs to the retailer or any retail overhead, price markups, or taxes. Source: http://www.nacsonline.com/yourbusiness/fuelsreports /gasprices_2008/pages/howtogetgas.aspx

In the context of this report, retail prices are the prices charged at the pump. All reported retail prices used in this report are either prices obtained directly from transactions or prices reported by users from fuel price signage at fueling stations. These prices are assumed to include state and local taxes in all instances.

A number assigned to qualifying renewable fuel and imparting monetary value under the Renewable Fuel Standard, the federal program that dictates minimum renewable fuel content for transportation fuels. Source: http://www.afdc.energy.gov/laws/RFS.html 


\section{Table of Contents}

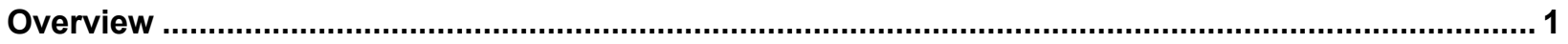

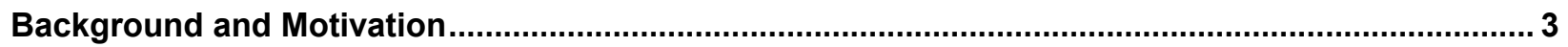

Methodology

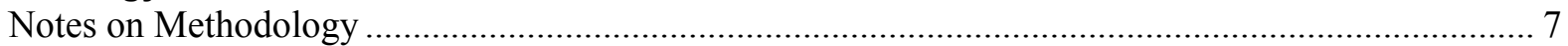

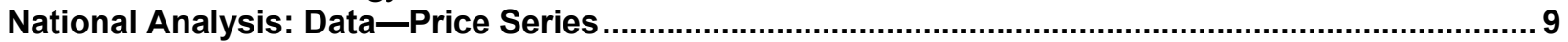

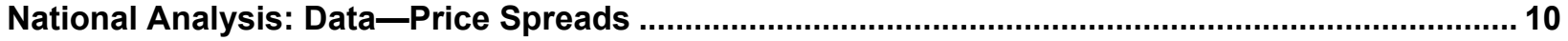

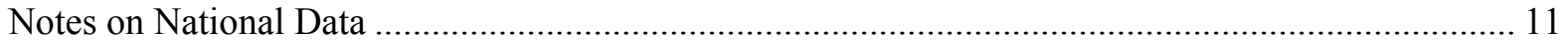

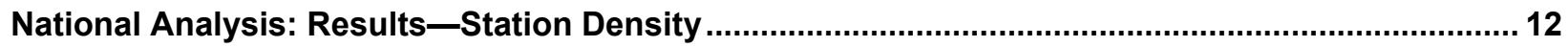

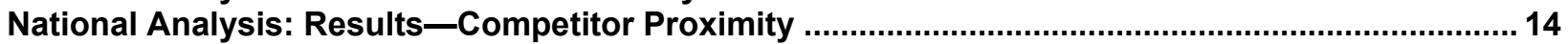

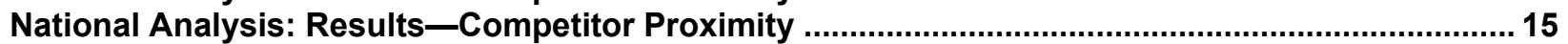

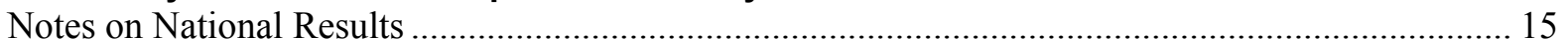

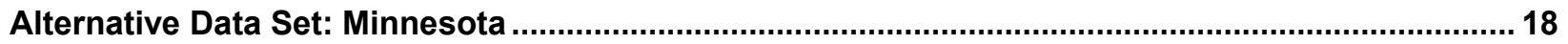

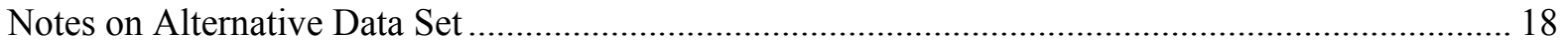

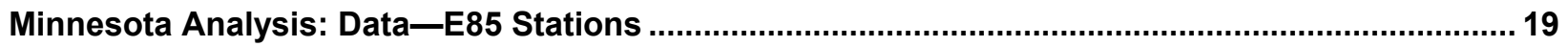

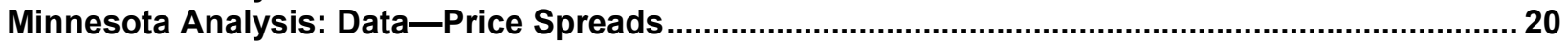

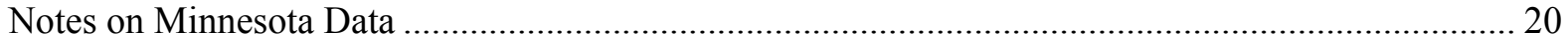

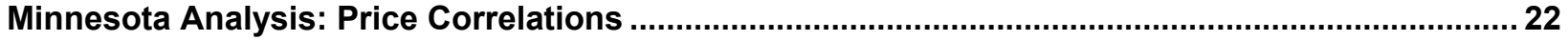

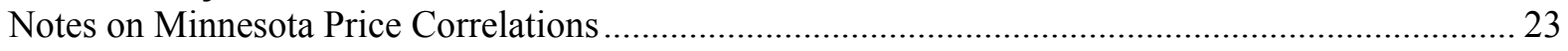

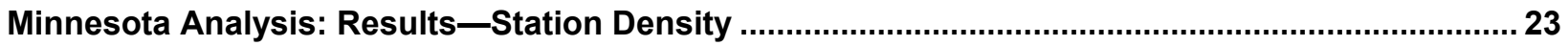

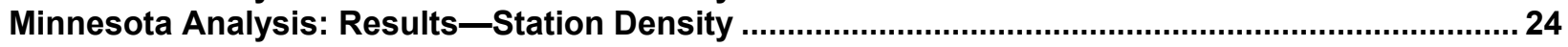

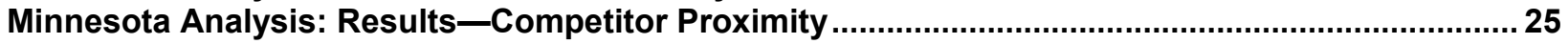

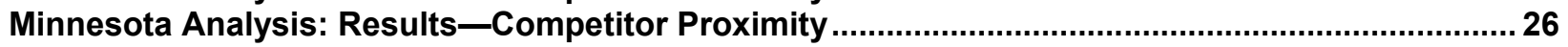

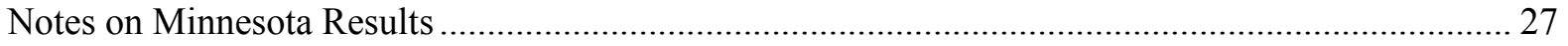

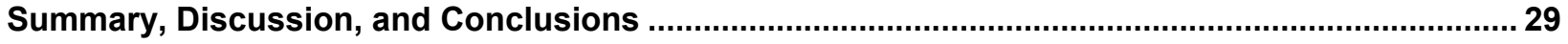

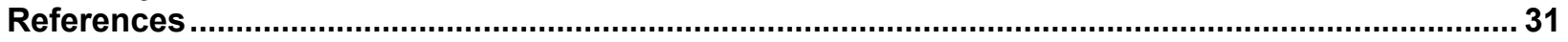

Appendix

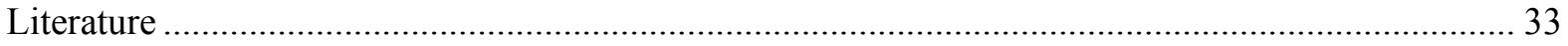

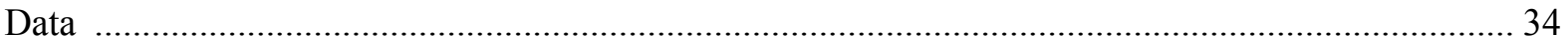

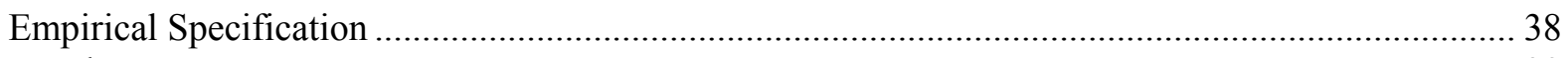

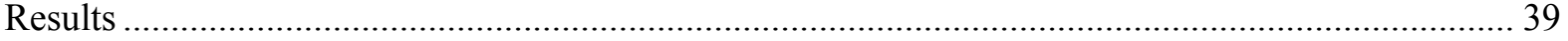




\section{List of Figures}

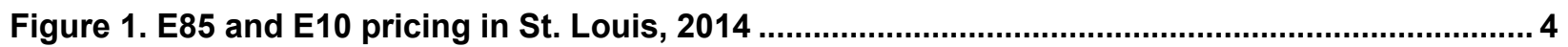

Figure 2. Retail margins for E85 and regular gasoline ................................................................ 5

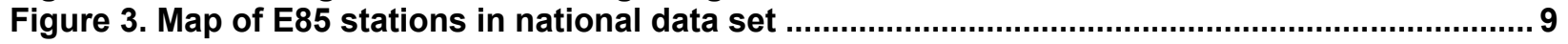

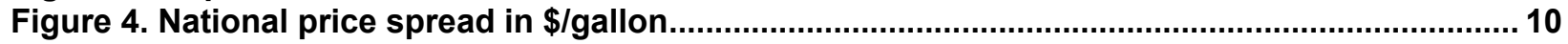

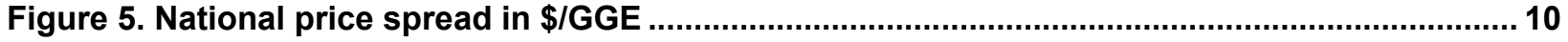

Figure 6. National station density pricing impacts: Absolute price ................................................ 12

Figure 7. National station density pricing impacts: Percent price ............................................... 13

Figure 8. National competitor proximity pricing impacts: Absolute price......................................... 14

Figure 9. National competitor proximity pricing impacts: Percent price ........................................... 15

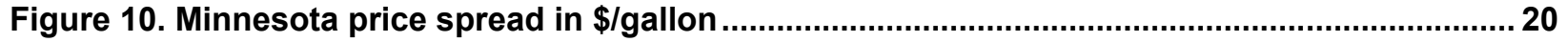

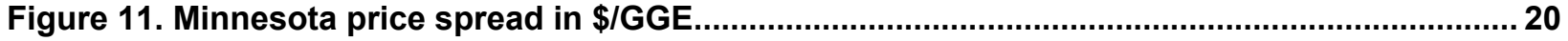

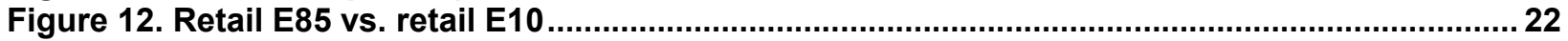

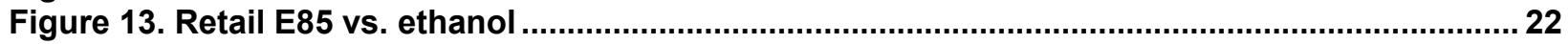

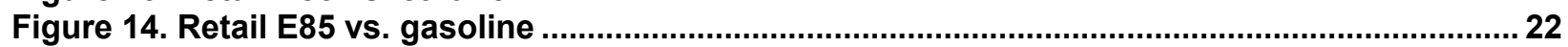

Figure 15. Minnesota station density pricing impacts: Absolute price..............................................2 23

Figure 16. Minnesota station density pricing impacts: Percent price ................................................2 24

Figure 17. Minnesota competitor proximity pricing impacts: Absolute price ................................... 25

Figure 18. Minnesota competitor proximity pricing impacts: Percent price .................................... 26

Figure A-1. Comparison of prices from OPIS and RFA data sets ................................................ 35

Figure A-2. Price spread in Minnesota by GGE with seasonal adjustment (top, repeated from

Figure 10) and without seasonal adjustment (bottom) .............................................................. 37

\section{List of Tables}

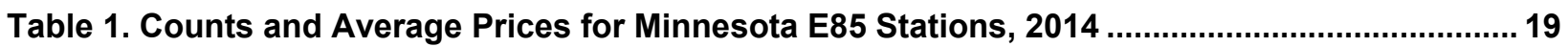

Table A-1. Seasonal and Geographic Volatility Classes for Minnesota Analysis ............................ 36

Table A-2. Sample Calculation of Spread in Gasoline Gallon Equivalents....................................... 36

Table A-3. Price Spreads in Minnesota by GGE with and without Seasonal Adjustment .................. 37

Table A-4. T-Statistics for Minnesota Fuel Price Calculations ....................................................... 42

Table A-5. Cross-Sectional Results: National Price Change ....................................................... 43

Table A-6. Cross-Sectional Results: National Percent Change ....................................................... 44

Table A-7. Within-Station Results: National Price Change .......................................................... 45

Table A-8. Within-Station Results: National Percent Change ...................................................... 46

Table A-9. Cross-Sectional Results: Minnesota Price Change ...................................................... 47

Table A-10. Cross-Sectional Results: Minnesota Percent Change ................................................... 48

Table A-11. Cross-Sectional Results: Minnesota Price Change with Brand Controls......................49

Table A-12. Cross-Sectional Results: Minnesota Percent Change with Brand Controls .................. 51

Table A-13. Cross-Section Analysis: Minnesota Price Change (OPIS Data Only) ...........................53

Table A-14. Cross-Section Analysis: Minnesota Price Change with Brand Controls (OPIS

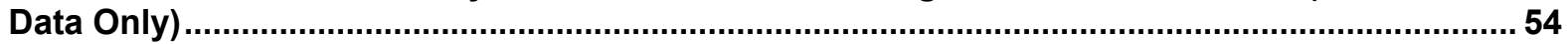




\section{Overview}

\section{Motivation}

- Assess retail pricing of E85

- Inform policy for future E85 expansion

- Provide benchmark prior to the U.S. Department of Agriculture's Biofuels Infrastructure Partnership

\section{Question}

- Does spatial competition in the market for E85 influence retail pricing behavior?

\section{Methods}

- Econometric analysis using panel data set of station-level wholesale and retail fuel prices

\section{Conclusion}

- Evidence of correlation between station density and E85 prices from publicly available data (e85prices.com) and purchased Minnesota data set (Oil Price Information Service)

- More station-level data may produce better-identified and more precise causal results

\section{Motivation}

This project developed from a general interest in understanding market penetration of high-blend ethanol fuels. The study focused on one key aspect of fuel adoption: retail pricing.

The findings presented here can inform future actions by revealing the effect of specific price determinants on retail E85 pricing. The price determinant of interest in this study is local market competition among E85 retailers.

Changes to local market competition are likely in the near future as the U.S. Department of Agriculture undertakes an aggressive infrastructure expansion program in the form of the Biofuels Infrastructure Partnership. This program provides more than \$210 million dollars in grants for new and updated ethanol blender pumps and other fuel infrastructure upgrades. ${ }^{1}$ The resulting increase in E85 availability has the potential to change the competitive landscape for E85 retailers. The analysis discussed here examines competitive effects in the period preceeding the Biofuels Infrastructure Partnership.

\section{Question}

This study is a preliminary attempt to quantify the effect of competition on retail E85 prices. Specifically, the analysis estimates the extent to which local retail competition affects E85 pricing. The amount of local competition is measured in terms of the density of nearby competitors and the distance to the nearest competing retailer.

\footnotetext{
${ }^{1}$ U.S. Department of Agriculture, "USDA Announces \$210 Million to be Invested in Renewable Energy Infrastructure through the Biofuel Infrastructure Partnership," USDA news release (Release No. 0300.15), October 28, 2015, https://www.usda.gov/wps/portal/usda/usdamediafb? contentid=2015/10/0300.xml.
} 


\section{Methods}

The analysis employed a fixed-effects econometric model to isolate the effect of spatial competition on E85 prices. The study used data from both a national publicly available fuel price data set as well as a proprietary data set of retail fuel prices in Minnesota in 2014 from the Oil Price Information Service (OPIS). To isolate and quantify the effect of local market power on E85 prices, the econometric model incorporated controls for wholesale costs and station-level attributes where available.

\section{Conclusions}

Results indicate correlation between station density and E85 prices. That is, higher levels of competition are associated with lower per-gallon E85 prices in a set of the scenarios tested. This correlation is present in the user-reported and proprietary data sets.

Causal interpretation of the resulting correlations (i.e., higher levels of local competition cause lower retail E85 prices) requires that a set of identifying assumptions be met by the econometric models and data. These requirements are described in detail in the appendix. While this study's findings are indicative of an inverse relationship between price and local competition, more and better data would allow for both better identified and more precise causal impacts. 


\section{Background and Motivation}

\section{What are recent findings regarding E85 pricing?}

- Retail E85 prices follow retail prices of regular gasoline.

- Margins for retail E85 are larger than margins for retail gasoline (Fuels Institute 2014).

Why is this important?

- Higher E85 prices limit adoption for price-sensitive consumers.

- Adopters in some areas pay prices that are higher than they would be under a counterfactual, cost-based pricing regime (RFA 2014).

\section{Where can we provide insight?}

- We investigated one potential cause of deviation from cost-based pricing (local market power)

- This partially addresses the limited national studies of E85 competition

\section{What are recent findings regarding E85 pricing?}

Data collected by the Renewable Fuels Association (RFA) for a set of retail E85 stations in St. Louis in 2014 are displayed in Figure 1 (next page). These price observations demonstrate that despite significant differences in input costs, E85 and E10 (regular) retail prices were highly correlated during the RFA's study period. Fuel input costs, in the form of rack prices, do not display the same level of correlation. ${ }^{2}$

\section{Why is this important?}

The RFA and Fuels Institute studies suggests that if E85 were priced based on marginal costs of production (similar to the gasoline market), E85 prices could be reduced. The importance of this suggestion is twofold:

1. Lower prices for high-blend ethanol fuels could create an increase in consumption if price-sensitive consumers increased their purchases.

2. Consumers who use E85 pay more for the fuel than would be charged in a counterfactual case with E85 prices based on costs of inputs.

A move toward cost-based pricing in the retail market for E85 may therefore increase consumption as well as increase overall consumer welfare. ${ }^{3}$

\footnotetext{
${ }^{2}$ RFA (2014) finds that "[d]uring the study period, E85 in St. Louis was discounted by an average of 12 percent [on a per-gallon basis] relative to E10 at the wholesale level. However, at the retail level, E85 was priced 1 percent above E10 on average."

${ }^{3}$ The extent of these changes in demand and consumer welfare is based on consumer preferences, specifically a willingness to substitute E85 for regular gasoline. Salvo and Huse (2013) and Anderson (2012) reveal heterogeneity in consumer responsiveness to price in the market for ethanol-based fuels.
} 


\section{Where can we provide insight?}

This study is motivated by the hypothesis that correlation between E85 and E10 retail prices signals a deviation from cost-based pricing. The analysis contributes to the understanding of pricing behavior in the high-blend ethanol fuel market and is the first national analysis to date that analyzes the effect of local market power on retailer E85 pricing behavior. ${ }^{4}$

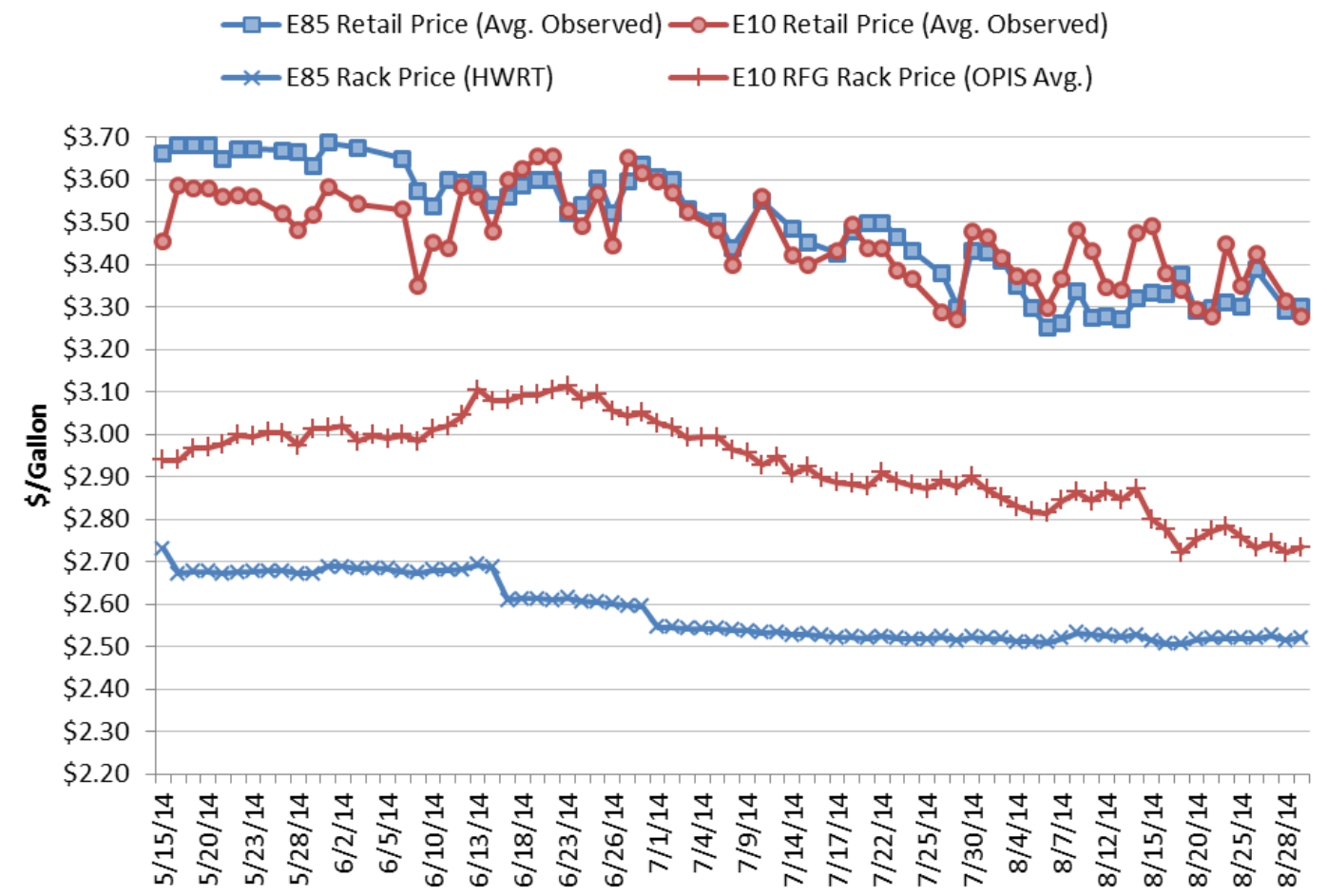

Figure 1. E85 and E10 pricing in St. Louis, 2014

Source: RFA 2014

E85 rack price from the HWRT Oil Company wholesale fuel terminal, and E10 reformulated gasoline (RFG) rack price data obtained from the Oil Price Information Service (OPIS) and retail prices from RFA study observations.

\footnotetext{
${ }^{4}$ Prior work has pointed to spatial competition as a possible factor influencing price, though this impact has not been studied specifically in the E85 market. In the gasoline market, the National Association of Convenience Store Owners states, "While wholesale costs are a significant factor in retailer [fuel] prices, the retail pricing decision also is heavily influenced by market conditions and local competition." (NACS, "How Do Retailers Get—and SellGasoline?" http://www.nacsonline.com/yourbusiness/fuelsreports/gasprices_2008/pages/howtogetgas.aspx). In the context of the E85 market, Anderson (2012) notes, "Retailers facing greater competition from other E85 retailers will tend to price at marginal cost, whereas retailers in less competitive areas can price according to willingness to pay (i.e., the price of gasoline)." Additional literature related to spatial competition effects in the retail gasoline market is discussed in the appendix.
} 
Another study, by the Fuels Institute (2014) analyzed data from a national sample of retail stations and computed average retail margins for both E85 and regular gasoline. As Figure 2 demonstrates, margins for retail E85 are consistently larger than those for retail gasoline.

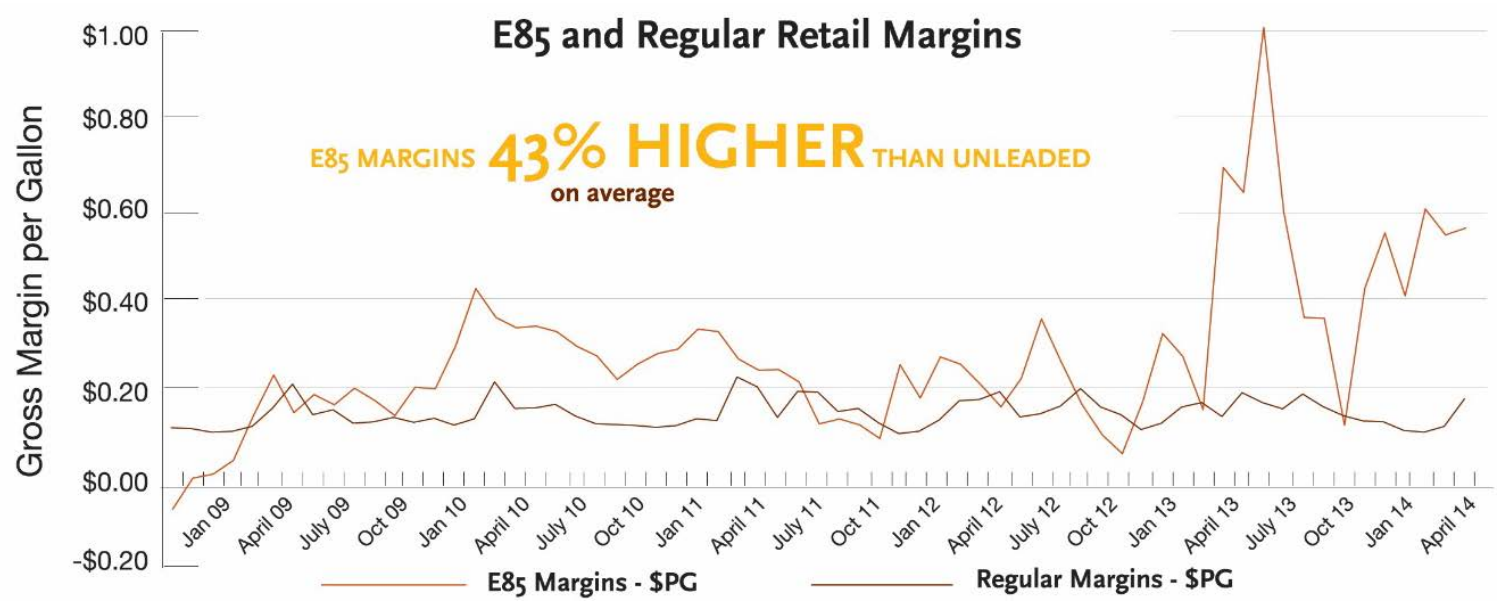

Figure 2. Retail margins for E85 and regular gasoline

Source: Fuels Institute 2014 (data from NACS CSX) ${ }^{5}$

$\$ P G=\$$ per gallon

\footnotetext{
${ }^{5}$ NACS was originally founded as the National Association of Convenience Stores. In 2007, it merged with CSX. For information about the merger, see PR Newswire, "NACS Acquires CSX," April 11, 2007, http://www.prnewswire.com/news-releases/nacs-acquires-csx-58237827.html.
} 


\section{Methodology}

\section{Data}

- Publicly available data set for United States, 2007-2015

- Price observations reported by individual users based on retail price signage and fuel purchases

- Sources: Renewable Fuels Association (RFA), e85prices.com

- Proprietary data set for Minnesota, 2014

- Fuel prices recorded from credit card transactions and direct feeds from retailers

- Source: Oil Price Information Service (OPIS)

- Both data sets report concurrent retail prices for regular gasoline and E85 at individual stations

\section{Competition Metrics}

- Number of competing E85 stations within a given radius

- Existing studies of this metric for retail gasoline: Lee (2007), Barron et al. (2004), Hastings et al. (2004)

- Evidence that lost retail gasoline sales are distributed to competing stations within a one-mile radius (Lee 2007)

- Distance to nearest station that offers E85

\section{Empirical Specifications}

- Across-station variation (cross-sectional analysis)

- Compare pricing among stations given variation in spatial competition faced by each station

- Control for time-invariant, spatial variation (e.g., density of flex-fuel vehicles [FFVs], access to highway infrastructure, local regulation) through spatial fixed effects

- Address national, time-varying effects (e.g., changes in E85 infrastructure costs, national trends in wholesale fuel cost, E85 familiarity and adoption) with temporal fixed effects

- Within-station variation

- Track price variation for a single station when number of nearby E85 competitors changes

- Replace spatial fixed effects with station-level fixed effects to control for station-level, timeinvariant effects (e.g., brand, location, amenities)

- All models control for same-day, same-station retail gasoline price.

- Estimates computed for local market power effects in terms of change in price (\$/gal) and percent change in price 


\section{Notes on Methodology}

\section{Notes on Data}

Observations for this study consist of regular gasoline and E85 prices at a particular station at an individual point in time. The national data set provides broad geographic coverage and a longer time series for analysis, which increases the number of observed changes in competition levels. The user-reported nature of the data set and lack of reported station-level characteristics may lead to imprecision or bias in the results. To confirm the findings in the national data set, the study also examines competitive impacts in a proprietary data set purchased from Oil Price Information Service. While these data only cover one year of retail pricing (2014) in a single state (Minnesota), their price reports and station-location information are assumed to be more accurate. See the data section of the appendix for details regarding the price data and additional data sets as well as a comparison of price observations in the RFA and OPIS data sets.

\section{Notes on Competition Metrics}

This study utilized station-level spatial competition metrics that are common in the retail gasoline literature: measures of station density and competitor proximity (Lee 2007; Barron et al. 2004; Hastings et al. 2004; Schultheis et al. 2016). For any given station that offers E85, the level of spatial competition in the market for E85 is represented by:

1. Station Density: number of stations within a given radius that also offer E85

2. Competitor Proximity: distance to the nearest station that offers E85.

All distance measures are computed on a linear basis. A range of radius specifications are employed to test the robustness of the station density metric. ${ }^{6}$ Competitor proximity is also classified in distinct categories, and this binned metric is used to account for possible nonlinearity in the price effect of a station's distance to its nearest competitor.

\section{Notes on Empirical Specifications}

This study exploits two sources of variation in the data to identify the effect of spatial competition on retail E85 pricing.

1. Cross-sectional analysis uses differences in station density and E85 price among stations. This method relies heavily on controls to isolate the effect of station density on pricing behavior. The econometric method controls for differences among stations in retail gasoline prices, distance to nearest ethanol terminal, and observed station and spatial attributes. These controls are implemented explicitly using available station attribute data, as well as captured in the specification's spatial and temporal fixed effects.

\footnotetext{
${ }^{6}$ The results of Lee (2007) suggest that retail sales for gasoline due to price increases are distributed among competing stations within a 1.0-mile radius. It is plausible that consumers adopting emerging, alternative fuels may travel out of their way to purchase these fuels. For example, Kuby, Kelley, and Schoenemann (2013) find that early adopters of natural gas vehicles demonstrate detours of up to six minutes to refuel. This is likely an upper bound to travel distances for flex-fuel vehicle owners; in contrast to natural gas, E85 has a readily available substitute in regular gasoline.
} 
2. Within-station analysis leverages the panel nature of the data set and uses observed changes in competition and prices at individual stations over time to identify the effect of spatial competition on pricing. This estimation strategy addresses some concerns related to inclusion of sufficient controls in the cross-sectional analysis.

The cross-sectional analysis includes more variation in the competition and price observations than the within-station analysis. This allows for estimates that are more precise. However, the across-station specification's lack of explicit controls (e.g., station attributes are not observed in our national data sample) leads causal interpretation to rely on the assumption that the included fixed effects capture other explanatory sources of variation in E85 prices. In contrast, the stationspecific fixed effects for the within-station method are more likely to capture confounding variation in the data than the spatial fixed effects of the across-station analysis, but there is less observed variation in the competition measure. This has the potential to make within-station estimates more accurate, but it decrease the model's precision. Additional discussion of the details of these estimation strategies and interpretation of results can be found in the appendix. 


\section{National Analysis: Data-Price Series}

\section{Compiled National Price Series}

- Publicly available, user-reported pricing data from e85prices.com

- Prices reported between January 2007 and August 2015

Figure 3. Map of E85 stations in national data set

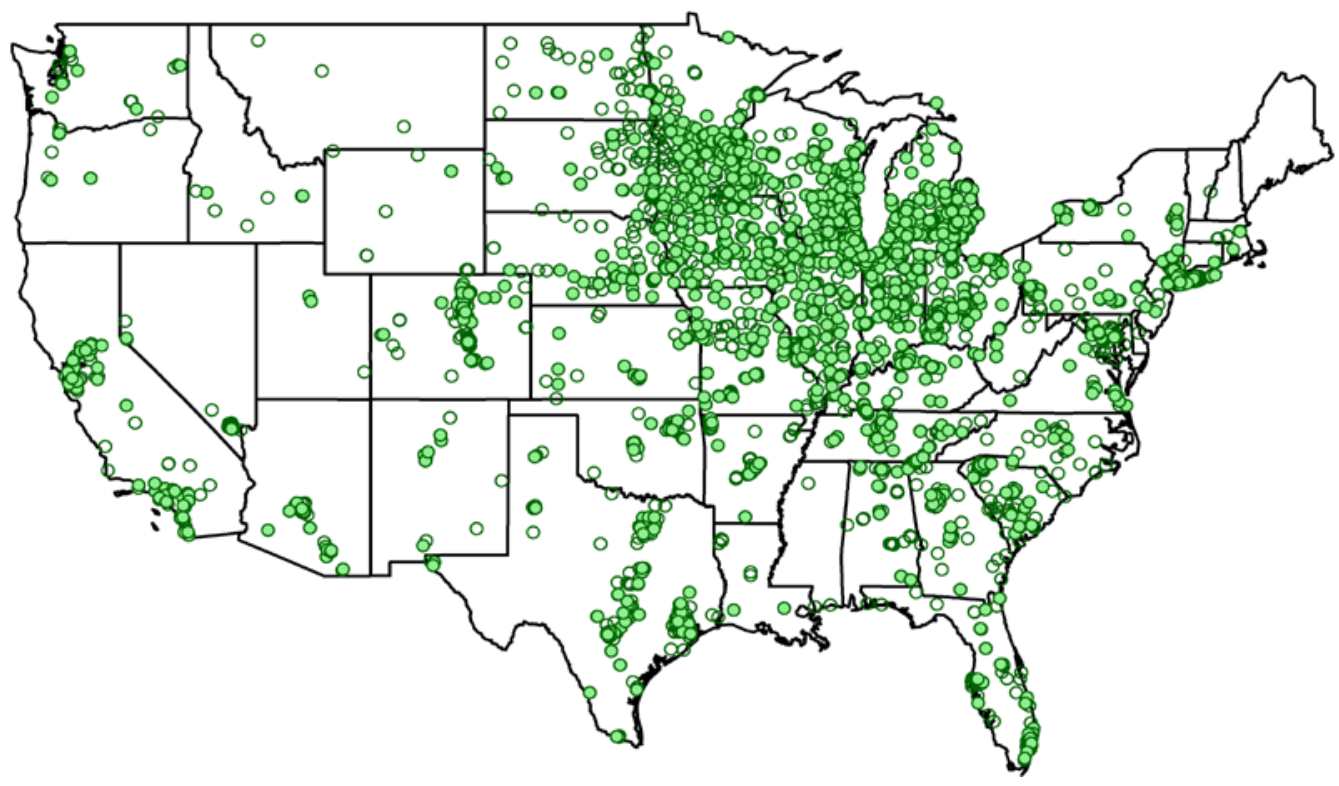

E85 stations per the Alternative Fuels Data Center (AFDC) (August 2015)

2,966

Stations with at least one RFA price observation

1,565

Mean number of price observation per station

25

Median number of price observation per station

7

Circles represent E85 stations. Circles with light green fill represent stations with at least one price observation.

Data were obtained from the AFDC website (www.afdc.energy.gov), E85Prices.com, and the Clean Cities program (cleancities.energy.gov). 


\section{National Analysis: Data-Price Spreads}

Figure 4. National price spread in \$/gallon

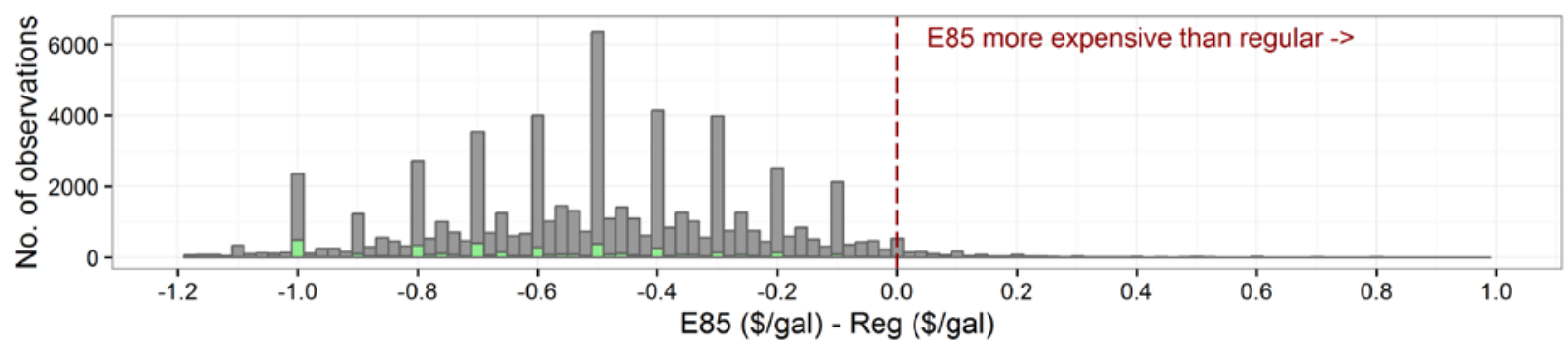

Figure 5. National price spread in \$/GGE

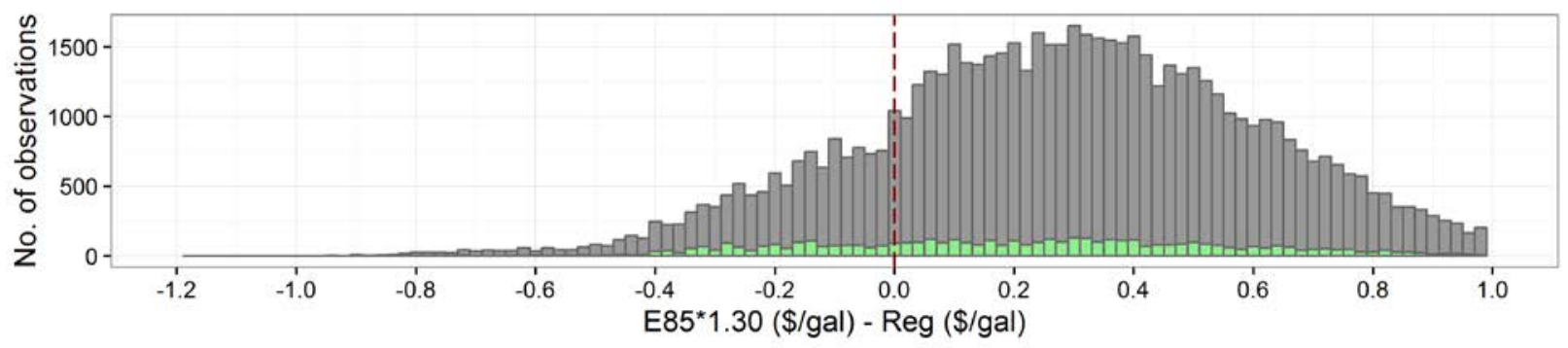

\begin{tabular}{|c|c|c|c|c|}
\hline \multirow{2}{*}{$\begin{array}{l}\text { Spread } \\
\text { units }\end{array}$} & \multirow{2}{*}{$\begin{array}{l}\text { Competitor } \\
\text { within One } \\
\text { Mile? }\end{array}$} & \multirow{2}{*}{$\begin{array}{l}\text { Number of Price } \\
\text { Observations }\end{array}$} & \multicolumn{2}{|c|}{ Percent of Price Observations } \\
\hline & & & $\begin{array}{l}\text { E85 Less Expensive than } \\
\text { Regular }\end{array}$ & $\begin{array}{l}\text { E85 More Expensive } \\
\text { than Regular }\end{array}$ \\
\hline \multirow{2}{*}{$\$ / g a l$} & No & 33,253 & 97.8 & 2.2 \\
\hline & Yes & 5,116 & 98.1 & 1.9 \\
\hline \multirow{2}{*}{ \$/GGE } & No & 33,253 & 22.4 & 77.6 \\
\hline & Yes & 5,116 & 28.2 & 71.8 \\
\hline
\end{tabular}

Gasoline gallon equivalent (GGE) assumes 70 percent ethanol blend.

[E85 \$/GGE]=[E85 \$/gal]*1.30.

Source: Clean Cities 2015 


\section{Notes on National Data}

\section{Compiled National Price Series (Figure 3)}

Data from the AFDC data set of alternative fueling locations indicate that 2,966 stations in the contiguous 48 states offer E85. After matching user-reported station locations and price observations with known station locations, approximately half of these stations had at least one price observation in the 8.5-year study period (January 2007 to August 2015).

Complete data coverage would include one price report per station, per day. As reported above, the average number of observations per station in the data set is 25 with a median of 7 . This indicates that the data set includes few well-populated price series for individual stations and that many stations in the data set have a small number of price reports. The limited number of comprehensive, station-level price series limits the precision of estimates obtained through the within-station empirical specification.

The geographic distribution of stations displayed in Figure 3 demonstrates the higher density of stations in the Midwest and provides some support for the selection of Minnesota for further analysis.

\section{Price Spread in National Data Set in Dollars per Gallon (Figure 4)}

Figure 4 displays observation-level differences between E85 prices and regular gasoline prices. Price spreads are calculated by subtracting the price of regular gasoline from the price of E85. Values less than zero indicate that E85 is less expensive than retail gasoline. The figure demonstrates that in the vast majority of price reports, the price per gallon of E85 is less than the price per gallon of regular gasoline. ${ }^{7}$

\section{Price Spread in in National Data Set in Gasoline Gallon Equivalent (Figure 5)}

A given volume of ethanol contains less energy than an identical volume of gasoline; accounting for this difference in energy density, Figure 5 and Table 1 present price differences in gasoline gallon equivalent (GGE) units. ${ }^{8}$ The results of computing the price spreads in the same manner (i.e., E85 price minus regular gasoline price) indicate that in a majority of the price reports, E85 is more expensive than regular gasoline on a GGE basis. These observations suggest one possible reason for limited E85 adoption-on an energy content basis E85 is frequently more expensive than regular gasoline.

\footnotetext{
${ }^{7}$ The aggregation of observations that creates the large spikes in the histogram reveals a tendency to price E85 at even, 10-cent discounts to regular gasoline. While this may be an indication of retailers pricing E85 relative to gasoline, it may also be attributable to rounding and aesthetic concerns with gasoline price signage.

${ }^{8}$ FFVs fueling with E85 can be expected to realize a 15\%-27\% decrease in fuel economy compared to fueling with E10. This range depends on the ethanol content of the E85 fuel (U.S. Department of Energy, "Ethanol,"

https://www.fueleconomy.gov/feg/ethanol.shtml). The spikes at certain price points present in Figure 4 disappear in Figure 5 due to the conversion from $\$ /$ gal to $\$ / G G E$.
} 


\section{Indications of Competition's Impact on Prices}

Price observations for stations with E85 competitors within a one-mile radius are highlighted in both Figure 4 and Figure 5. Without controlling for any other differences among observations, there is some indication that E85 is more competitive with gasoline at stations with competitors nearby. This is demonstrated in the last two rows of the Table 1, which shows that E85 is less expensive than regular gasoline on a GGE basis in $28 \%$ of price observations at stations with a competitor within 1.0 miles, compared to $22 \%$ where the nearest competitor is outside 1.0 miles.

Notes on the national analysis results follow the figures.

\section{National Analysis: Results-Station Density}

Figure 6. National station density pricing impacts: Absolute price

Number of stations within ...

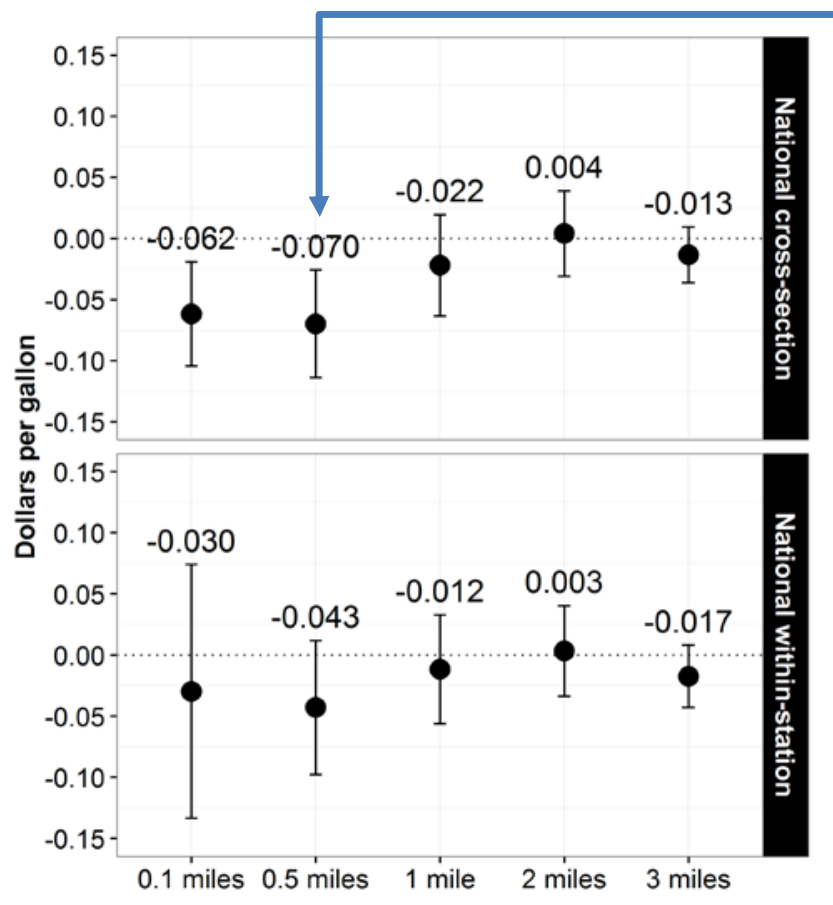

Dots and labels indicate point estimate values.

Error bars represent $95 \%$ confidence intervals.
Interpretation: One more station offering E85 within 0.5 miles is associated with a $\$ 0.07$ lower E85 price per gallon, all else being equal. Confidence intervals indicate estimates range from approximately $\$ 0.11$ to $-\$ 0.03$.

\section{Cross-Sectional Results}

- Spatial competition associated with lower E85 pricing within 0.5 miles

\section{Within-Station Results}

- Point estimates suggest possible inverse relationship between E85 prices and spatial density

- Coefficient estimates for variables of interest lack statistical significance

- Imprecise estimates likely result from limited number of observable price and station density changes (e.g., 5 identifying stations at 0.1 miles for within-station analysis) 


\section{National Analysis: Results—Station Density}

Figure 7. National station density pricing impacts: Percent price

Number of stations within ...

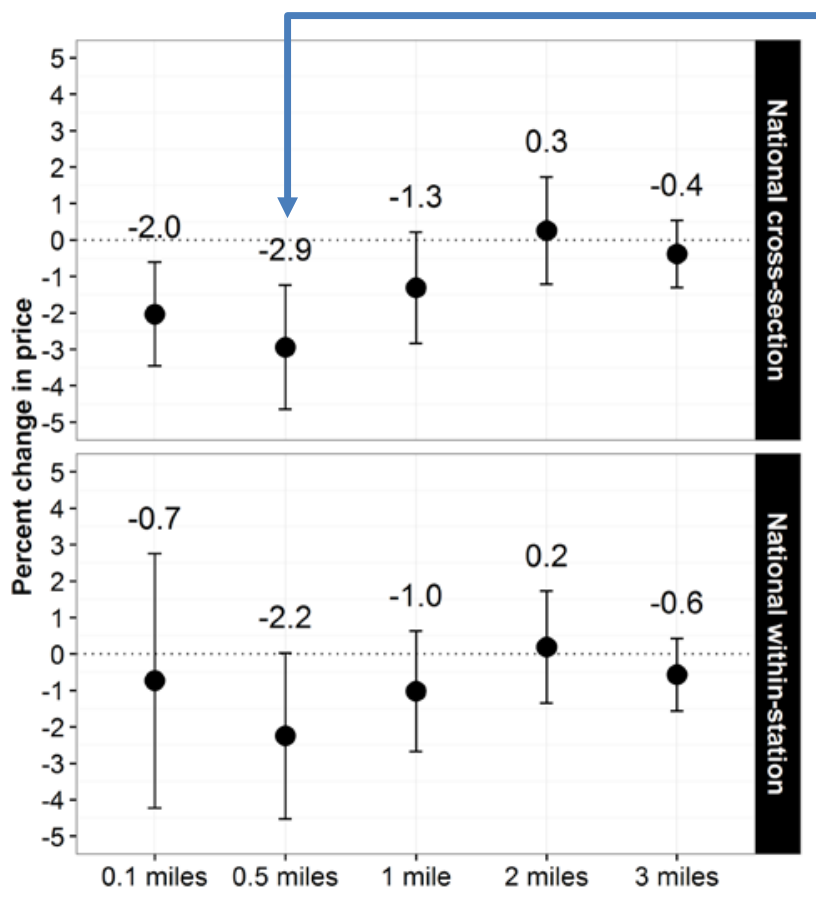

Interpretation: One more station offering E85 within 0.5 miles is associated with a 2.9 percent lower E85 price per gallon, all else equal. Confidence intervals indicate estimates range from approximately 1.2 to -4.6 percent.

Impacts in percent price change

- Point estimates of competition effect are qualitatively similar to level price changes

- Cross-sectional analysis of competitive effects within 0.5 miles maintains significance at the 95 percent level

Dots and labels indicate point estimate values.

Error bars represent $95 \%$ confidence intervals. 


\section{National Analysis: Results-Competitor Proximity}

Figure 8. National competitor proximity pricing impacts:

Absolute price

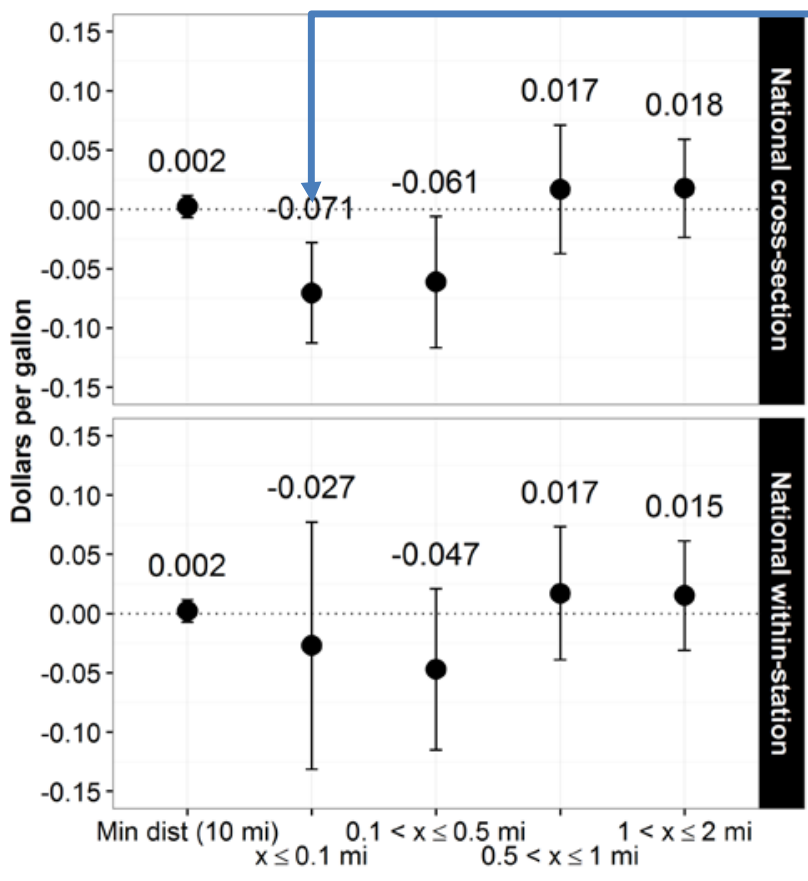

Dots and labels indicate point estimate values. Error bars represent $95 \%$ confidence intervals. The omitted bin is nearest competitor more than two miles away.
Interpretation: A station whose nearest competitor is within 0.1 miles will price E85 approximately \$0.07 per gallon lower than an otherwise identical station whose nearest competitor is more than two miles away.

\section{Linear Minimum Distance Metric}

- Neither cross-section nor withinstation specification indicates a statistically significant relationship between nearest competitor distance and E85 pricing

- Result possibly due to non-linear relationship between competitor proximity and E85 price

\section{Binned Minimum Distance Metric}

- Cross-sectional analysis reveals a statistically significant relationship within 0.5 miles

- Within-station results lack precision, but point estimates display a pattern similar to the cross-sectional result 


\section{National Analysis: Results-Competitor Proximity}

Figure 9. National competitor proximity pricing impacts:

Percent price

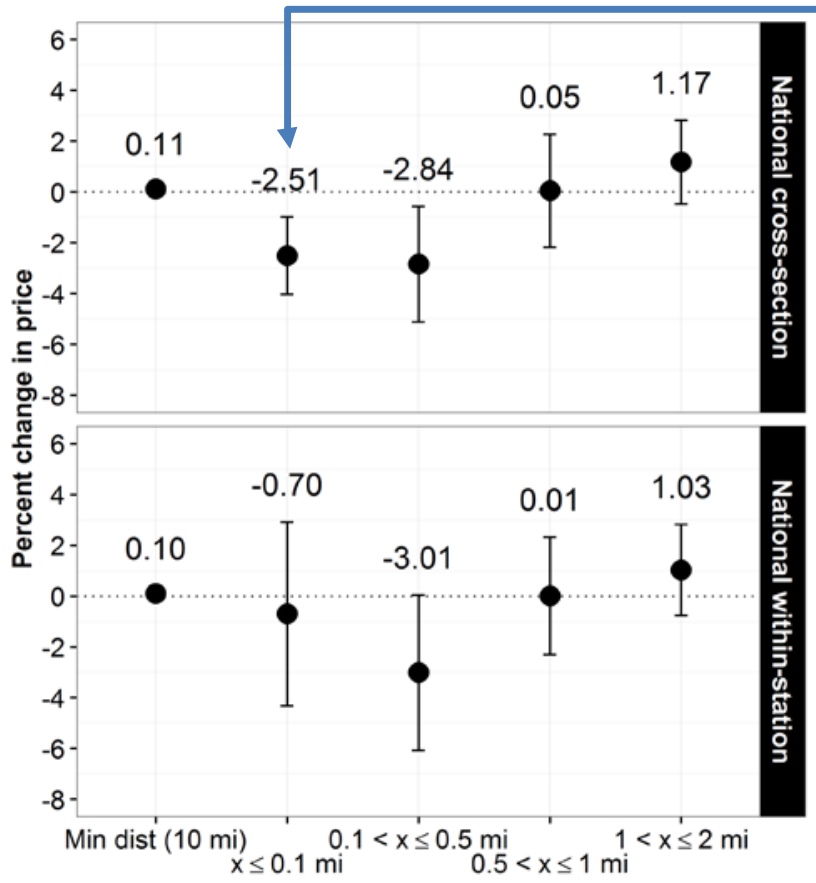

Interpretation: A station whose nearest competitor is within 0.1 miles is associated with a 2.9 percent lower E85 price per gallon than an otherwise identical station whose nearest competitor is more than two miles away.

\section{Impacts in percent price change}

- Point estimates of competition effect are qualitatively similar to price changes

- Cross-sectional analysis of competitive effects within 0.5 miles maintains significance at the 95 percent level

Dots and labels indicate point estimate values. Error bars represent $95 \%$ confidence intervals.

The omitted bin is nearest competitor more than two miles away.

\section{Notes on National Results}

Detailed tables and additional discussion of results are included in the appendix.

\section{Interpretation of Results Figures}

Each black dot in Figures 6 through 9 represents a point estimate that should be interpreted as described in the blue-bordered box that accompanies each figure. The bars extending above and below each point indicate the precision of this estimate. That is, the actual value for this measure in the underlying population is likely to fall within the range of the vertical bars. Instances in which these error bars cross the dashed zero line indicate that we cannot say with certainty that the point estimate is non-zero (i.e., we cannot reject the null hypothesis that there is no impact). 


\section{Cross-Sectional Results, Price Change (Figure 6, top panel)}

Cross-sectional analysis for the price change specification suggests that spatial competition within 0.5 miles is associated with lower E85 prices at fuel stations, all else being equal. The point estimates indicate that the impact of one more station within 0.5 miles is to reduce the price of E85 by approximately 7 cents per gallon. Subject to the assumptions of the cross-sectional specification, point estimates within 0.5 miles indicate an inverse relationship between station density and E85 retail prices.

\section{Within-Station Results, Price Change (Figure 6, bottom panel)}

Within-station results similarly suggest an inverse relationship between density of competing stations and E85 price on the order of a few cents per gallon, though results are not statistically significant. The imprecision of these results is likely due to the limited number of stations with variation in the level of local competition over the study period. This is the variation used to identify the effects estimated by the econometric model, and hence, a small number of "identifying stations" decreases the precision of the results. In the context of the national data set, over the 8.5-year study period, only 21 stations with price data had another station within 0.5 miles begin offering E85. This number decreases to five stations when the competitive radius is restricted to 0.1 miles.

\section{Station Density Results, Percent Change (Figure 7)}

Allowing competitive density to affect pricing on a percentage basis, results and significance levels are similar. As in the price change estimation, cross-sectional results show statistically significant estimates of lower E85 prices within 0.5 miles. Point estimates for percent changes for within-station analysis follow this pattern, though they do not maintain statistical significance.

Consistent findings of inverse correlation between spatial density and E85 pricing indicate a relationship may be present, but data limitations likely contribute to imprecise results for the within-station analysis. These results do not address endogeneity concerns, discussed in more detail in the appendix.

\section{Linear Minimum Distance Metric, Price Change (Figure 8, left column)}

The left-most "column" of Figure 8 represents the estimated impact of competitor proximity on retail E85 pricing. Point estimates of 0.002 in both specifications indicate that for each additional 10 miles between a retailer and its nearest competitor, E85 prices are observed to be 0.2 cents higher. This point estimate is, however, not statistically different from zero in either specification. Given the findings of the station density analysis, it is reasonable to suspect that the effects of competition do not scale linearly. This may explain the lack of a significant finding using a linear specification. 


\section{Binned Minimum Distance Metric, Price Change (Figure 8, right four columns)}

Rather than assume a linear relationship between a station's distance to its nearest competitor and its reported E85 prices, the binned competition metric groups stations into distinct categories based on competitor proximity. Stations are classified by distance to nearest competitor into five bins: within 0.1 miles, between 0.1 and 0.5 miles, between 0.5 and 1.0 miles, between 1.0 and 2.0 miles, and beyond 2.0 miles. Regression analysis with groupings such as these provides flexibility in the model's specification; the use of categorized competitor distance allows for different estimates of competitive effect for each bin.

Interpretation of results of the binned regressions (Figure 8, top panel, Columns 2-5) requires comparison of point estimates to the omitted category (i.e., stations with a nearest competitor outside a two mile radius). That is, a station with at least one E85 competitor within 0.1 miles prices E85 \$0.07 per gallon lower than an otherwise identical station whose nearest competitor is more than two miles away. It is also possible to compare results across bins. For example, results of the cross-sectional analysis indicate that a station with a competitor within 0.1 miles prices E85 \$0.01 per gallon less on average (\$0.071-\$0.061) than an otherwise identical station that has its closest competitor between 0.1 and 0.5 miles away. The similarity of these point estimates and their corresponding ranges (as shown by the error bars for each point estimate in the figure) demonstrates that this difference is not statistically significant.

Identification using the within-station methodology is imprecise, though point estimates suggest a pattern that is similar to that of the cross-sectional analysis: lower per-gallon E85 prices for stations with nearest competitors within 0.5 miles, all else being equal.

\section{Continuous and Binned Distance Metrics, Percent Change (Figure 9)}

As in the case of measures of competitive density, allowing price impacts on a percentage basis results in qualitatively similar indications of competitive impacts. The linear distance metric produces positive, but not statistically significant results. Binned distance metrics suggest statistically significant inverse effects within a 0.5 mile radius. 


\section{Alternative Data Set: Minnesota}

\section{Oil Price Information Service (OPIS) Proprietary Retail Price Data}

- Station-level prices and station attributes for all Minnesota stations in 2014

- Daily prices for regular gasoline and E85 purchases included in data set

- Minnesota identified as best candidate for data purchase based on conversations with OPIS personnel and analysis of E85 station entry from AFDC data

- Cross-referenced OPIS price reports with AFDC station identification data and RFA user-reported prices from e85prices.com

- Where possible, supplemented data with RFA observations

\section{Notes on Alternative Data Set}

To reinforce the national findings, the methodologies discussed above were applied to a proprietary OPIS data set of fuel prices in Minnesota in 2014. The proprietary data set potentially provides more consistency in both price data and price controls, which could increase precision of the spatial effect estimates. Project budget constraints limited the preliminary analysis to a single state and year combination. Data for Minnesota in 2014 were selected on the advice of OPIS analysts to maximize the comprehensiveness of E85 price coverage and station entry observations.

Notes on the Minnesota analysis data follow the figures. 


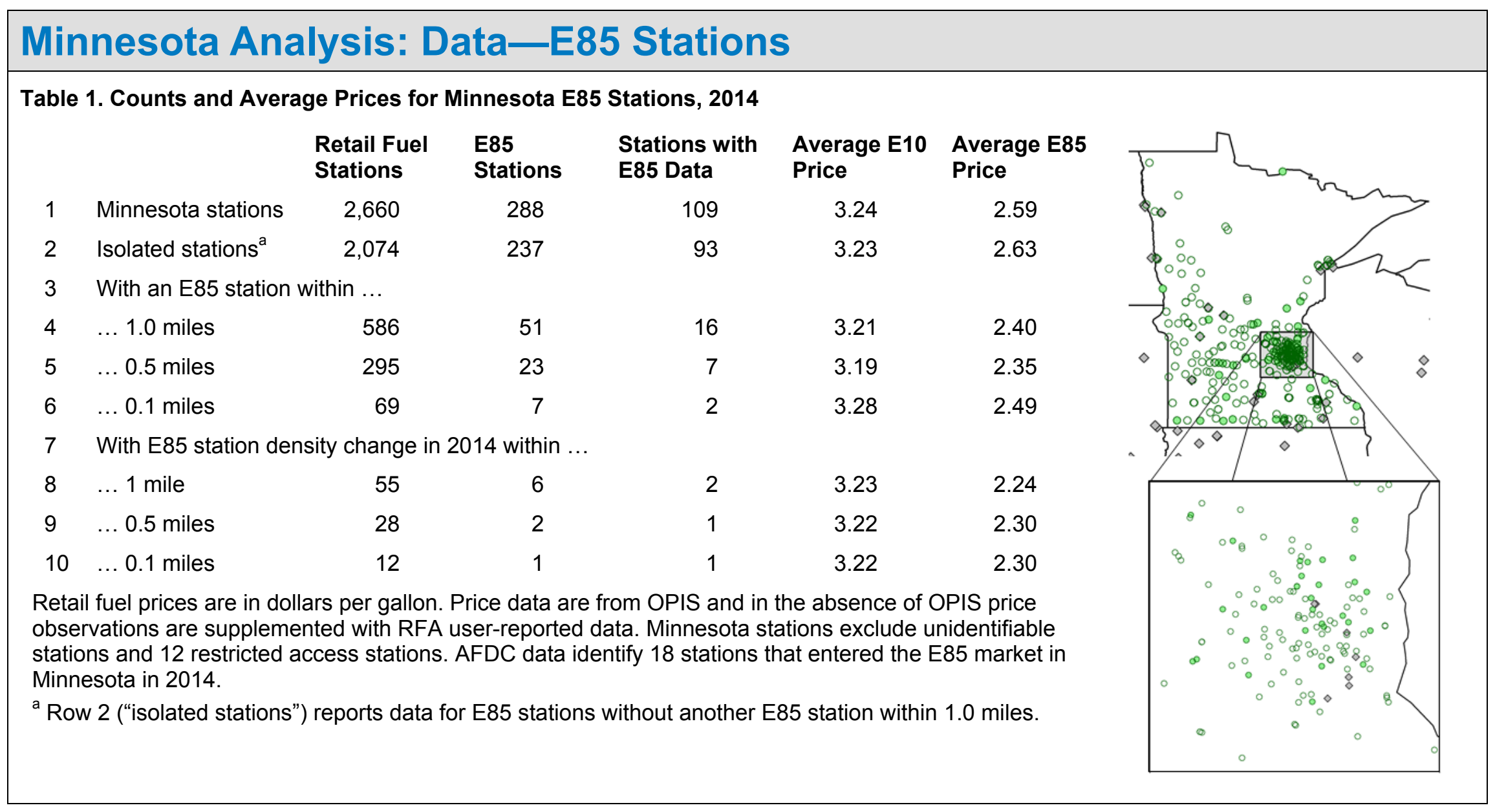




\section{Minnesota Analysis: Data-Price Spreads}

Figure 10. Minnesota price spread in \$/gallon

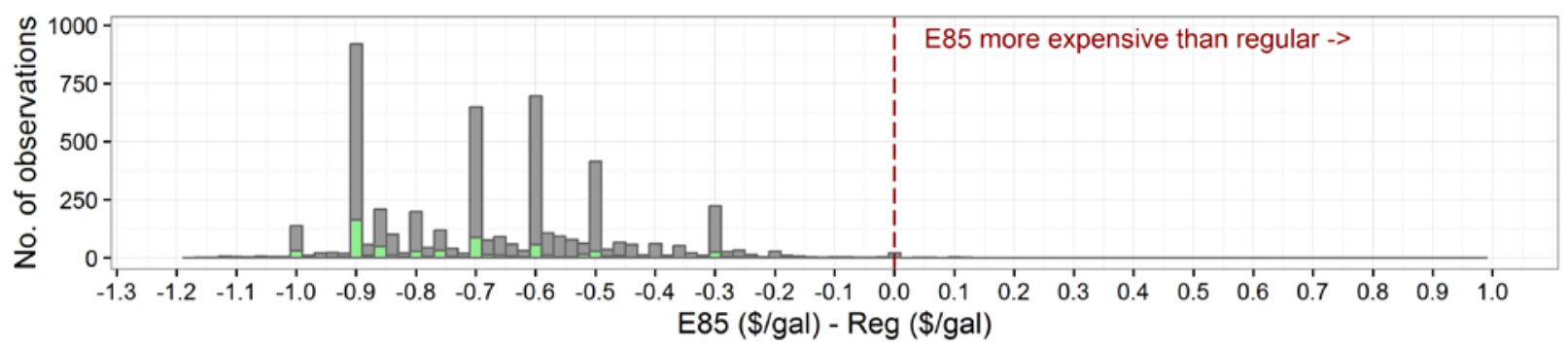

Figure 11. Minnesota price spread in \$/GGE

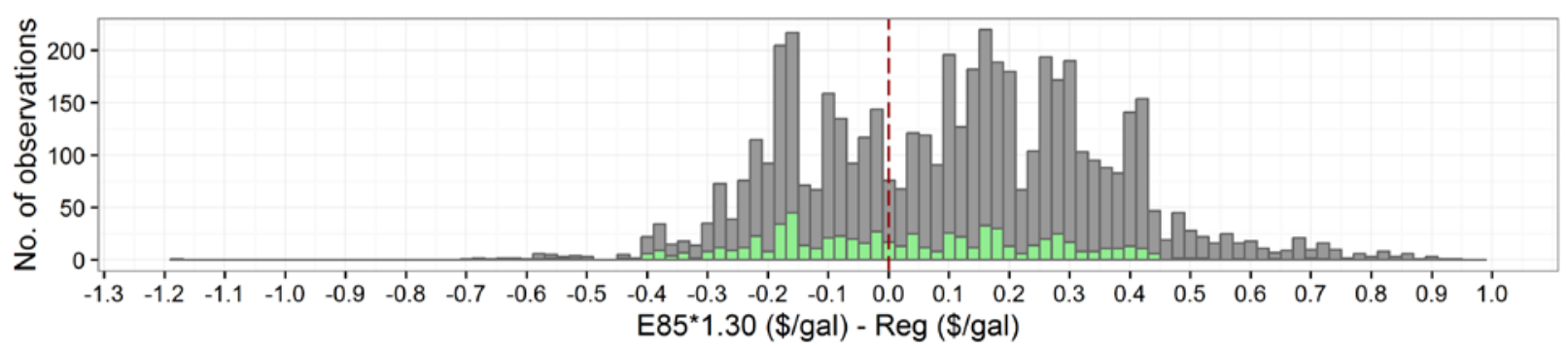

\begin{tabular}{|c|c|c|c|c|}
\hline \multirow[b]{2}{*}{ Spread Units } & \multirow[b]{2}{*}{$\begin{array}{l}\text { Competitor } \\
\text { within One Mile? }\end{array}$} & \multirow[b]{2}{*}{$\begin{array}{l}\text { Number of } \\
\text { Price } \\
\text { Observations }\end{array}$} & \multicolumn{2}{|c|}{ Percent of Price Observations } \\
\hline & & & $\begin{array}{l}\text { E85 Less } \\
\text { Expensive than } \\
\text { Regular }\end{array}$ & $\begin{array}{l}\text { E85 More } \\
\text { Expensive than } \\
\text { Regular }\end{array}$ \\
\hline \multirow[t]{2}{*}{$\$ / g a l$} & No & 4,354 & 99.7 & 0.3 \\
\hline & Yes & 708 & 99.8 & 0.2 \\
\hline \multirow[t]{2}{*}{$\$ / G G E$} & No & 4,354 & 33.7 & 66.3 \\
\hline & Yes & 708 & 48.4 & 51.6 \\
\hline
\end{tabular}

\section{Notes on Minnesota Data}

\section{Data}

Table 1 summarizes station counts and average prices in 2014 from the combined OPIS/RFA data set.

1. Stations with local market power (i.e., no E85 competitors within one mile) have higher average E85 prices on a per gallon basis. Row 2 of the table, labeled "isolated stations," reports data for E85 stations without another E85 station within one mile. Note that there are 93 stations with price observations, and the average E85 price in 2014 in these stations is $\$ 2.63$ per gallon. This can be compared to the data in Row 4 of the table, which indicates 16 stations with E85 price data have another E85 station within 1.0 miles. 
While the average E10 price at these stations is the same as the price at the isolated stations, the average E85 price is $\$ 0.23$ per gallon lower. This result and the result for the 0.5 -mile radius (Row 5 of the table) demonstrate statistically significant lower prices for non-isolated stations. ${ }^{9}$

2. E85 pricing data remains sparse. Comparing the columns labeled "E85 stations" and "Stations with E85 data" illustrates this point. For example, Row 1 of the table indicates that this data set includes pricing data for 109 of the 288 E85 stations in the state in 2014. The data in Row 8 indicate that at six stations in 2014, the level of spatial competition within 1.0 miles changed. Of these six stations, E85 price observations are available for only two.

The price difference calculations above are only illustrative, and it is plausible that stations in Rows 4 and 5 are fundamentally different (e.g., stations with nearby competitors may often be in urban settings that are closer to fuel distribution and more densely populated than the "isolated stations"). These factors may lower costs and drive additional price competition not attributed strictly to station density. These concerns are addressed through the econometric specifications discussed previously. Specifically, cross-sectional analysis controls for variation in these factors using time-invariant, spatial fixed effects. Causal interpretation of econometric results relies on the assumption that these factors do not change substantially within 2014.

Figures 10 and 11 parallel Figures 4 and 5 for the Minnesota price data. A GGE conversion factor of 1.3 (i.e., assuming 70\% ethanol content for E85) is used for ease of comparison to Figure 5. A detailed spread calculation based on assumptions of seasonal variation in ethanol content can be found in Figure A-1 in the appendix.

\section{Price Spread in Dollars per Gallon}

Similar to Figure 4, the price per gallon of E85 is consistently less than the price per gallon of regular gasoline.

\section{Price Spread in Dollars per Gasoline Gallon Equivalent}

The Minnesota data reveal a difference in price spreads on a GGE basis for stations that experience local competition. Stations without competitors within a one-mile radius price ethanol above E10 on a GGE basis more often than stations with competitors nearby. Approximately $48 \%$ of price observations at stations with another E85 station within a 1.0 miles show an E85 price less than gasoline on a GGE basis, which is significantly higher than the 34\% of price observations for stations without an E85 competitor nearby. While not causal, this is a possible indicator of local market power impacts in the retail E85 market.

While Minnesota has the greatest public availability of E85 of any state ${ }^{10}$, price observations indicate that E85 still struggles to be competitive with gasoline on a GGE basis.

\footnotetext{
${ }^{9}$ All other station competition measures (e.g., Rows 6 and 8-10) are not significantly different from zero due to the small number of price observations. Sample averages and associated t-statistics are included in Table A-3 of the appendix.

${ }^{10}$ Minnesota leads the United States with the highest level of public E85 availability with 291 E85 stations as of August 2016 (AFDC, "Alternative Fueling Station Counts by State,"

http://www.afdc.energy.gov/fuels/stations_counts.html).
} 


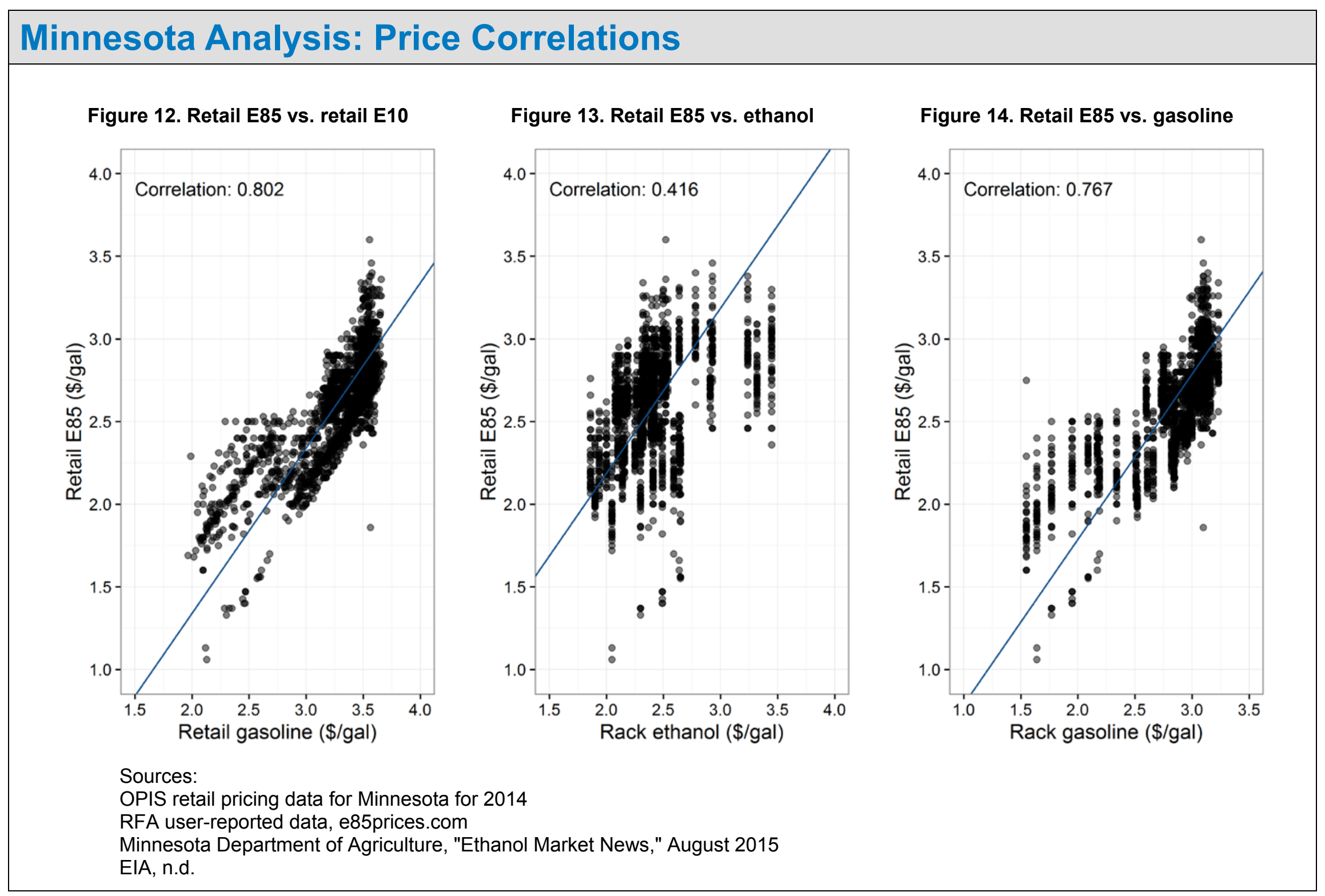




\section{Notes on Minnesota Price Correlations}

Scatter plots of weekly average retail and rack price observations are presented in Figures 12-14, with a reference line with slope equal to 1 . Figure 12 (left) displays a scatter of retail prices, while Figures 13 and 14 relate the retail price of E85 to rack prices of its component parts: ethanol (center) and gasoline (right).

Taken together, these plots indicate that retail E85 prices have a stronger correlation with retail E10 prices than with rack prices for ethanol, its primary component. ${ }^{11}$ This result is in line with the findings of the St. Louis RFA study (Figure 1) and may indicate a deviation from cost-based pricing for E85.

Notes on the Minnesota analysis results follow the figures.

\section{Minnesota Analysis: Results—Station Density}

Figure 15. Minnesota station density pricing impacts:

\section{Absolute price}

Number of stations within ...

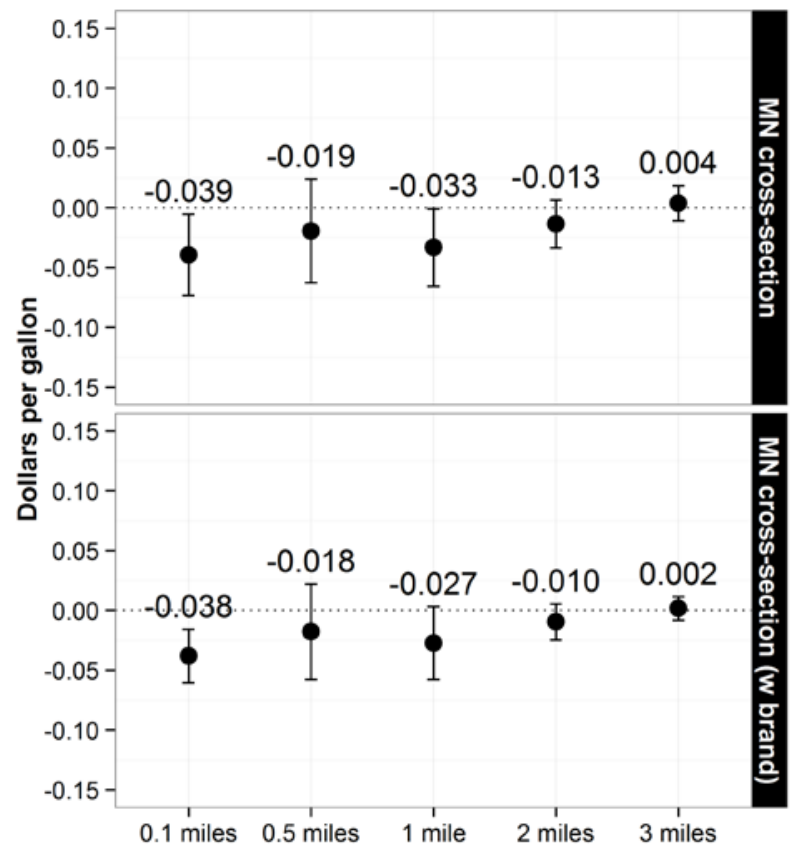

Cross-Sectional Results

- Spatial competition associated with lower E85 pricing within one mile

- Insufficient identifying variation in data set for within-station analysis

- Two stations with variation within 1.0 miles and one station with variation within 0.1 miles.

- Refinement with station brand controls produces similar point estimates and decreases variance

\footnotetext{
${ }^{11}$ The rack prices for ethanol do not include renewable identification number (RIN) values. While it is possible that this decreases the correlation between retail E85 prices and rack ethanol prices, this impact is likely minimal. There was limited fluctuation in D6 RIN prices in 2014, varying from approximately $\$ 0.35$ to $\$ 0.45$ per credit. (For a D6 RIN price series, see Figure 2 of Knittel, Meiselman, and Stock [2015].)
} 


\section{Minnesota Analysis: Results-Station Density}

Figure 16. Minnesota station density pricing impacts:

Percent price

Number of stations within ...

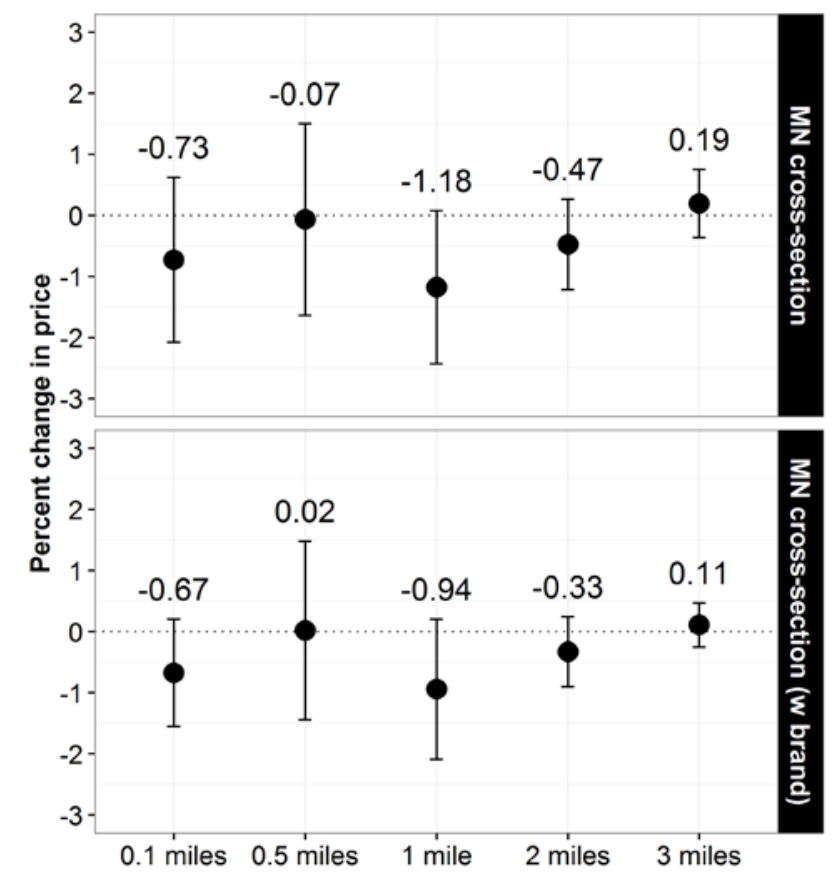

Impacts in percent price change

- Point estimates of competition effect are qualitatively similar to level price changes

- No estimates demonstrate statistical significance at the 95 percent level 


\section{Minnesota Analysis: Results-Competitor Proximity}

Figure 17. Minnesota competitor proximity pricing impacts: Absolute price

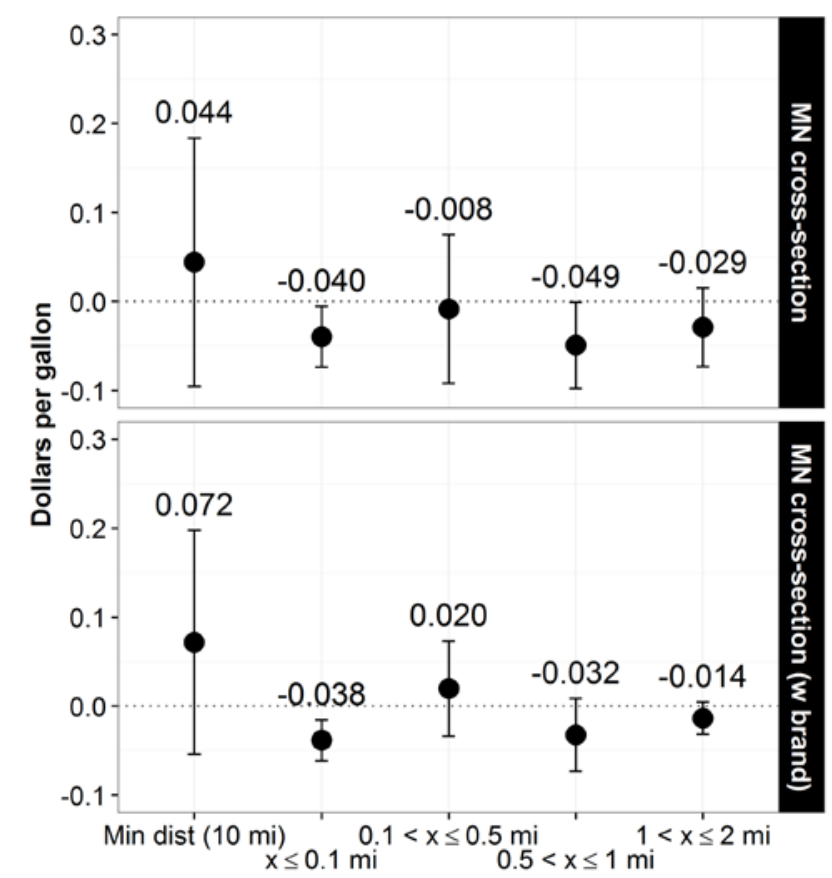

\section{Linear Minimum Distance Metric}

- Point estimates are of larger magnitude than in national analysis

- Specifications do not suggest a statistically significant, linear relationship between $\mathrm{E} 85$ retailer proximity and E85 price

\section{Binned Minimum Distance Metric}

- Both specifications indicate a statistically significant effect for station competition within one tenth of a mile

- Effects for bins beyond 0.1 miles lack sufficient precision to assign a nonzero effect 


\section{Minnesota Analysis: Results-Competitor Proximity}

Figure 18. Minnesota competitor proximity pricing impacts: Percent price

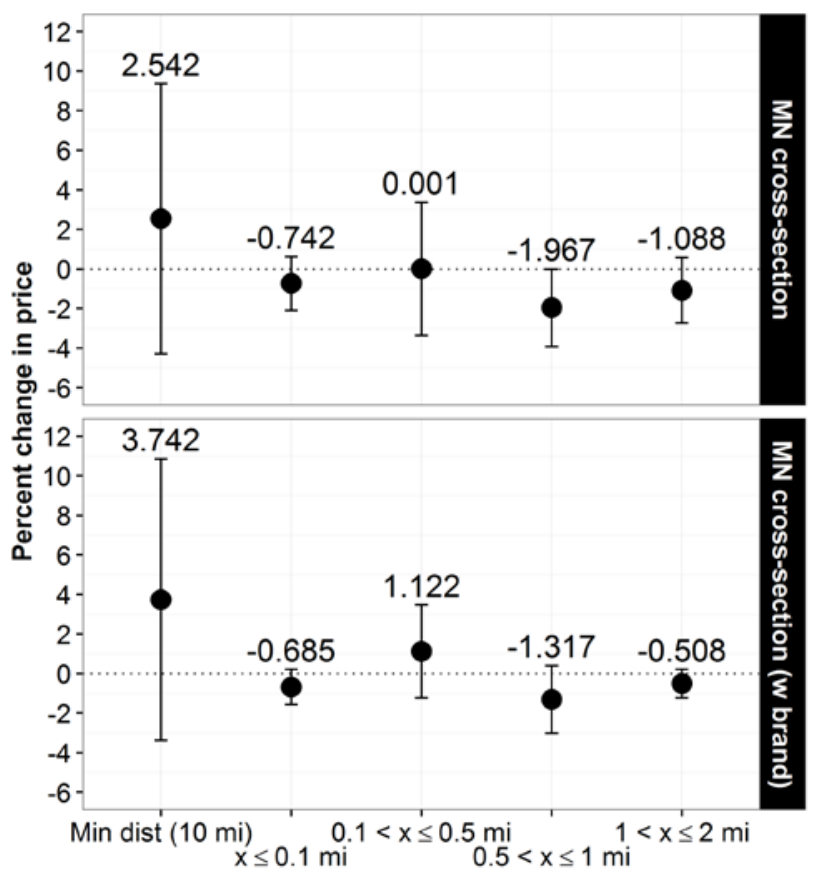

\section{Impacts in percent price change}

- Point estimates of competition effect are again qualitatively similar to level price changes

- No estimates demonstrate statistical significance at the 95 percent level 


\section{Notes on Minnesota Results}

Detailed tables and additional discussion of results are included in the appendix.

\section{Interpretation of Results Figures}

Each black dot in Figures 15 through 18 represents a point estimate that should be interpreted as described in the blue-bordered box in corresponding national results figure (Figures 6-9). The bars extending above and below each point estimate indicate the precision of this estimate. That is, the actual value for this measure in the underlying population is likely to fall within the range of the vertical bars. Instances in which these error bars cross the dashed zero line indicate that we cannot say with certainty that the point estimate is non-zero (i.e., we cannot reject the null hypothesis that there is no impact).

\section{Competitive Density Results, Price Change (Figure 15)}

Cross-sectional analysis of the Minnesota data set produces point estimates of similar direction and magnitude to those found in the national analysis. However, with the exception of estimates at the 0.1-mile radius, these results still lack robust statistical significance. While results with the Minnesota data set are not definitive, they suggest possible competitive effects within a one mile radius.

The proprietary data set includes information on station brand, a control not consistently available in the national data. Inclusion of station brand as a control reduces some noise in the data and hence narrows the confidence intervals of each point estimate. This inclusion also reduces the potential for bias due to omitted variables, which is discussed in detail in the appendix. While this specification is an improvement, it does not drastically alter significance for estimates outside one-tenth of a mile.

As suggested by the total station counts presented in Table 2 and discussed above, the Minnesota data lack a sufficient number of stations with a change in station density and price observations to apply the within-station methodology.

\section{Competitive Density Results, Percent Change (Figure 16)}

Estimates of competitive density impacts on price on a percentage basis indicate point estimate trends similar to estimates of price changes. The imprecision of these estimates leads to nonstatistically significant results for the cross-section analysis with and without station brand controls.

Interpretation of linear and binned distance results are similar to those outlined for Figure 8.

\section{Linear Minimum Distance Metric (Figures 17 and 18, left column)}

In concert with the results of the national analysis, the use of a linear measure of competitor proximity does not produce a statistically significant result for price changes or percent changes in price. This again indicates that price effects of competition may not scale linearly in the market for E85. 


\section{Binned Minimum Distance Metric (Figures 17 and 18, right four columns)}

A nonlinear specification, using identical bins to those used in the national analysis, suggests statistically significant impacts within 0.1 miles for the price change specification (Figure 17).A station whose nearest competitor is less than 0.1 mile away prices E85 approximately $\$ 0.04$ per gallon less than an otherwise identical station whose nearest competitor in the E85 market is more than two miles away. This result does not persist under a percent price change specification (Figure 18).

The results of none of the econometric specification for the Minnesota data produce statistically significant point estimates for bins beyond the 0.1-mile range. 


\section{Summary, Discussion, and Conclusions}

\section{Descriptive Analysis}

- Correlation between E10 and E85 retail pricing

- Evidence that E85 price differences are possibly due to local market power

\section{Econometric Analysis}

- Inverse relationship between retail E85 prices and station density

- Indications of nonlinear effect of competitor proximity on E85 prices

\section{Data Availability-A Primary Concern for Future Analysis of E85 Pricing Behavior}

- Current sources (RFA, OPIS) lack comprehensive retail price coverage for E85

- Improved data may produce more precise and better-identified results

\section{Descriptive Analysis}

- Examination of simple scatter plots of E85 prices against regular gasoline and its component parts reveals higher levels of correlation with E10 and wholesale gasoline prices than ethanol costs. This indicates that E85 may in fact be priced with respect to its substitute fuel, not based on its inputs.

- Analysis of price spreads demonstrates some difference in spreads based on proximity to the nearest E85 competitor. Average E85 prices for stations in Minnesota in 2014 vary based on the number of competitors within one mile. While both observations lack spatial or temporal controls, they indicate spreads and E85 prices are not uniform when levels of local competition vary.

\section{Econometric Analysis}

- Across specifications and data sources, the results of this study are indicative of local competition effects on E85 prices.

- When local competition is measured as station density, competition influences E85 prices within 0.5 miles. Across-station analysis using the national data set indicates the magnitude of retail price impact of one additional competitor is on the order of six to seven cents per gallon. On a percentage change basis, results suggest one more competitor within a 0.5 mile radius may decrease $\mathrm{E} 85$ prices by two to three percent.

- These findings are based on observations with a small number of local competitors (i.e., a maximum of two competitors within 0.5 miles) and there is no evidence that this trend would continue linearly outside of this observed range.

- Measured as competitor proximity, binned results potentially indicate nonlinear effects of distance to a station's nearest competitor and E85 pricing. Magnitudes of this effect vary based on the choice of empirical specification and price data set.

- The precision of the results varies across specifications: 
- The cross-sectional model produces results that are consistently more precise, though it relies on a more tenuous assumption that the model's fixed effects control for any confounding variation.

- The fixed effects for the within-station specification are more likely to satisfy this assumption and can therefore more readily support a causal interpretation; however, a lack of observations that have variation in the competitive measures of interest produces less precise results.

\section{Data Availability}

- The preliminary analysis conducted in this study could be improved using more price data and more comprehensive controls. Specifically, improvements to the cross-sectional model's empirical specification through the addition of more explanatory variables would address concerns about omitted controls. Possible candidates to improve the specification include station attributes at the national level, station-level fuel costs, time-varying local FFV demand, or drivers' familiarity with, and interest in, high-blend ethanol fuels.

- The lack of precision encountered by the within-station model could be addressed by collecting more complete fuel price time-series observations from stations that see a change in the level of local competition. A longer and more complete time series would both increase the number of stations used to identify an effect and reduce concerns that reporting stations are not representative of the wider population of E85 retailers. At a minimum, data collected from stations that observe nearby E85 retail entry both before and after the entry occurs could be used to bolster the within-station analysis.

Details regarding the project background, data, and results are available in the appendix. 


\section{References}

Anderson, S. 2012. "The Demand for Ethanol as a Gasoline Substitute.” Journal of Environmental Economics and Management 63(2):151-168.

Barron, J.M., B.A. Taylor, and J.R. Umbeck. 2004. "Number of Sellers, Average Prices, and Price Dispersion.” International Journal of Industrial Organization 22(8):1041-1066.

Bromiley, P., T. Gerlach, K. Marczak, M. Taylor, and L. Dobrovolny. 2008. Statistical Analysis of the Factors Influencing Consumer Use of E85. Golden, CO: National Renewable Energy Laboratory. NREL/SR-540-42984.

Deltas, G. 2008. "Retail Gasoline Price Dynamics and Local Market Power.” The Journal of Industrial Economics 56(3):613-628.

DOE (U.S. Department of Energy). 2015. Clean Cities Alternative Fuel Price Report. http://www.afdc.energy.gov/uploads/publication/alternative_fuel_price_report_july_2015.pdf

- 2016. "Handbook for Handling, Storing, and Dispensing E85 and Other EthanolGasoline Blends.” February 2016.

EIA (U.S. Energy Information Administration). n.d. "Minnesota Regular Gasoline Wholesale/Resale Price by

Refiners." https://www.eia.gov/dnav/pet/hist/LeafHandler.ashx?n=PET\&s=EMA_EPMR_PWG SMN DPG\& $=$ $=$ M.

Fuels Institute. 2014, November. E85: A Market Performance Analysis and Forecast.

Hastings, J. S. 2004. "Vertical Relationships and Competition in Retail Gasoline Markets: Empirical Evidence from Contract Changes in Southern California." American Economic Review 94(1):317-328.

Hosken, D. S., R. S. McMillan, and C. T. Taylor. 2008. "Retail Gasoline Pricing: What Do We Know?” International Journal of Industrial Organization 26(6):1425-1436.

Johnson, C., and M. Melendez. 2007. E85 Retail Business Case: When and Why to Sell E85. Golden, CO: National Renewable Energy Laboratory. NREL/TP-540-41590.

Knittel, C. R., B. S. Meiselman, B. S., and J. H. Stock. 2015. "The Pass-through of RIN Prices to Wholesale and Retail Fuels under the Renewable Fuel Standard." National Bureau of Economic Research. Working paper no. 21343.

Kuby, M. J., S. B. Kelley, and J. Schoenemann. 2013. "Spatial Refueling Patterns of AlternativeFuel and Gasoline Vehicle Drivers in Los Angeles." Transportation Research Part D: Transport and Environment 25:84-92.

Lee, S. Y. 2007. "Spatial Competition in the Retail Gasoline Market: An Equilibrium Approach Using SAR Models." The Ohio State University. Working paper. 
Liu, C., and D. Greene. 2014. "Consumer Choice of E85 Denatured Ethanol Fuel Blend: Price Sensitivity and Cost of Limited Fuel Availability." Transportation Research Record: Journal of the Transportation Research Board 2454: 20-27.

Melaina, M., and J. Bremson. 2008. "Refueling Availability for Alternative Fuel Vehicle Markets: Sufficient Urban Station Coverage.” Energy Policy 36(8):3233-3241.

Minnesota Department of Agriculture. 2015, August. Ethanol Market News.

Minnesota Department of Commerce. n.d. Minnesota E85 + Mid-blends Station Report. http://mn.gov/commerce-stat/pdfs/e85-fuel-use-2014.pdf.

Pouliot, S., and B. A. Babcock. 2014. "The Demand for E85: Geographical Location and Retail Capacity Constraints.” Energy Economics 45:134-143.

RFA (Renewable Fuels Association). 2014. Evidence of E85 Price Gouging? A Case Study of the St. Louis E85 Market. Renewable Fuels Association. http://www.ethanolrfa.org/wpcontent/uploads/2015/09/Evidence-of-E85-Price-Gouging.pdf.

Rosen, S. 1974. "Hedonic Prices and Implicit Markets: Product Differentiation in Pure Competition.” Journal of Political Economy 82(1):34-55.

Salvo, A., and C. Huse. 2013. "Build It, But Will They Come? Evidence from Consumer Choice between Gasoline and Sugarcane Ethanol." Journal of Environmental Economics and Management 66(2):251-279.

Schultheis, Amy, Daniel N.K. Johnson, Kristina M. Lybecker, and Devin Nadar. 2016. "Buy Here, or Keep Driving? The Effect of Geographic Market Density on Retail Gas Prices." Journal of Business 1(2), 12-20.

Shaked, A., and J. Sutton. 1982. "Relaxing Price Competition through Product Differentiation." The Review of Economic Studies 49(1):3-13.

Shriver, S. K. 2015. "Network Effects in Alternative Fuel Adoption: Empirical Analysis of the Market for Ethanol." Marketing Science 34(1):78-97. 


\section{Appendix}

\section{Literature}

Competitive retail pricing strategies are widely studied in the economics literature. The standard price competition framework (i.e., Bertrand competition) dictates that in a perfectly competitive environment with identical goods, all firms select prices such that price equals marginal cost. When products are differentiated, prices may deviate from marginal cost. The extent of this deviation is based on consumer preferences and perception of differences among products (Rosen 1974; Shaked and Sutton 1982). In practice, retail transportation fuel is differentiated along a number of dimensions (e.g., station location, fuel additives, loyalty programs, and convenience store access) and retail competition to meet demand is geographically constrained. Controlling for other attributes, this study focuses on product differentiation along the spatial dimension and its effect on retail fuel pricing - specifically whether local market power influences E85 pricing. The nature of E85 as an emerging fuel alternative creates valuable heterogeneity of E85 availability that we exploit to examine this issue.

Price-cost margins and spatial competition in the market for retail gasoline in the United States have been extensively studied in a variety of geographic locations. Deltas (2008) suggests that retail margins in the market for gasoline are influenced by the level of retail market power of firms. The empirical models of Hastings et al. (2004) and Hosken, McMillan, and Taylor (2008) both specify distance to nearest competitor as a control, though they do not focus specifically on this component as a variable of interest. Barron et al. (2004) and Lee (2007) undertake studies of retail spatial competition and include measures of station density as an indicator of local market power. Both Barron et al. and Lee reveal negative correlations between prices and station density. In a preliminary estimation step, Lee concludes that sales lost due to price changes at a given station are capture by competing stations within a 1.0-mile radius. Barron et al. find direct correlation between station density and pricing at the 1.5 -mile radius. The specifications used herein incorporate a number of model radii as well as the distance to the nearest station, following the specifications and results of the above-mentioned studies.

While the literature regarding retail gasoline addresses firm-level spatial competition, limited work focuses on this issue in the market for E85. Several studies cover impacts of fuel infrastructure expansion on adoption and the impact of E85 pricing on demand (Melaina and Bremson 2008; Pouliot and Babcock 2014; Bromiley et al. 2008; Liu and Greene 2014; Shriver 2015). The contribution of spatial competition to retail pricing warrants separate study in the E85 market as, in contrast to retail gasoline, E85 is emerging fueling alternative in the United States. For this reason, firms offering E85 have more potential to exploit local market power and consumers may respond differently to E85 price differences across fueling stations. A refined understanding of spatial market competition in the E85 market could have important implications for current and future infrastructure expansion policy. 


\section{Data}

\section{Data for Estimation}

Publicly available retail E85 and gasoline prices were obtained from the Renewable Fuels Associations' e85prices.com website, which aggregates user-reported fuel prices from stations within the United States. Data were extracted from the website's archives, and observations span January 2007 to August 2015. Additional price observations from regional coordinators of the U.S. Department of Energy's Clean Cities program were collected for the same period, and the two data sets were combined to create a data set of national, user-reported, daily E85 and regular gasoline price observations. As all data points from these sources were user-reported, care was taken to standardize addresses and associated latitude/longitude pairs and remove duplicated pricing observations where possible. In the case of conflicting or incomplete information, manual searches of stations were undertaken and observations with unclear or imprecise identifying information were omitted. Dates for which stations began offering E85 are based on information available from the AFDC. In the event of conflicting information between station open dates and E85 transaction dates, open dates were assumed correct. The resulting data set included at least one price observation for 1,565 stations within the 8.5 -year period. The publicly available price data, in conjunction with the AFDC data, suggest that as of August 2015, there are 2,966 unique stations offering E85 within the United States.

The limited coverage of these data has important implications for our analysis, as discussed in detail in the empirical specification section (below). In an effort to improve the price coverage of our data set, we also employed proprietary gasoline and E85 retail prices from OPIS. ${ }^{12}$ As data coverage for some states was limited, the analysis focused on Minnesota in 2014. These data were combined with the user reported observations from the national data set to produce 5,197 individual price observations for 288 stations within Minnesota in $2014 .{ }^{13}$ As can be seen in Figure A-1, price observations were similar between the RFA and OPIS data sets. In the case of conflict between OPIS and RFA prices, OPIS prices were used. As demonstrated in Table A-13 and Table A-13, sole reliance on OPIS prices does not qualitatively change results.

\footnotetext{
12 The OPIS data were included in an effort to improve both data coverage and accuracy. OPIS prices were collected directly from fuel purchase transactions, and they are passed through algorithms to remove erroneous data points (OPIS, “OPIS Methodology: OPIS Retail Gasoline Pricing," http://www.opisnet.com/about/methodology.aspx\#RetailGas).

${ }^{13}$ The population of 288 stations is similar to the 293 stations offering E85 as reported in Minnesota Department of Commerce, n.d.
} 

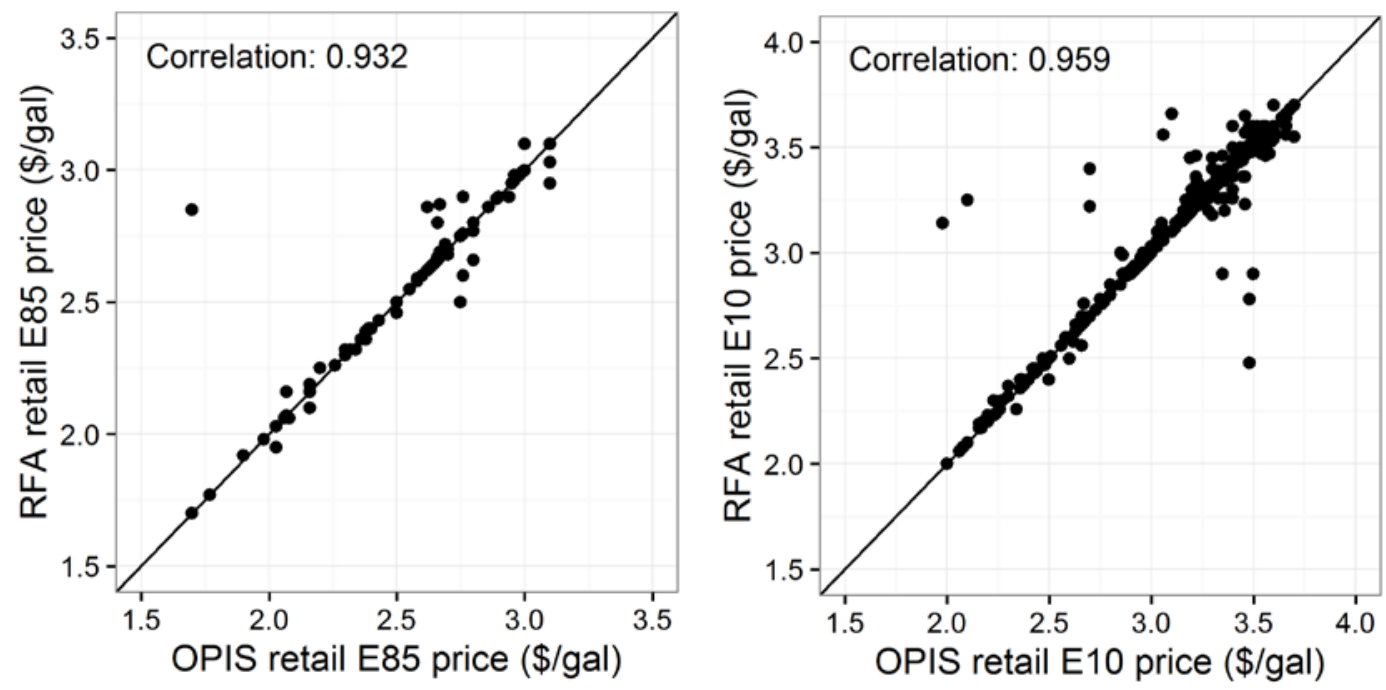

Figure A-1. Comparison of prices from OPIS and RFA data sets

The figure includes all instances where both OPIS and RFA data sets include prices for the same station on the same day.

To control for cost differences among observations, distances to the nearest ethanol terminal were computed for all stations in both samples using an ethanol terminal location data set from OPIS. Rack ethanol prices were obtained from Minnesota Department of Agriculture Ethanol Market News reports, and they represent rack prices in Minneapolis and St. Paul. Gasoline rack prices are Omaha, Nebraska rack prices obtained from cstoredecisions.com. Various rack locations available through cstoredecisions.com were compared, and Omaha was selected as the closest approximation to state-level, monthly wholesale gasoline prices from the U.S. Energy Information Administration.

\section{Computation of GGE Spreads}

E85 is a moniker for fuels that consist of $51 \%$ to $83 \%$ ethanol. The majority of the remaining content of E85 is gasoline. Pure ethanol (E100) and pure gasoline (E0) contain different amounts of energy per gallon. When comparing prices of E85 and regular gasoline, it is important to account for this energy difference by computing E85 prices in GGE. As ethanol content varies and is not recorded in either the user-reported or proprietary data, the computations in Figure 5 and Figure 9 use a conversion factor of 1.30, which corresponds to fuel that is $70 \%$ ethanol by volume, to transform E85 prices in dollars per gallon to dollars per GGE. ${ }^{14}$

The amount of ethanol in a gallon of E85 varies seasonally to address vapor pressure requirements and to avoid vehicle start-up issues in cold temperatures. These "seasonal and geographic volatility classes" vary by state and month. Information on these classes for Minnesota is available in Table A-1. ${ }^{15}$ For ease of comparing Minnesota data to the national data, these volatility class calculations were not presented in the body of this report. However, accounting for the seasonal changes in ethanol content seen in E85 (see Figure A-2) further

\footnotetext{
${ }^{14}$ For details about this conversion, see DOE (2015).

${ }^{15}$ Classes for all states are available in DOE (2016, Appendix E, Table E1).
} 
reinforces the suggestion that E85 struggles to be competitive with gasoline on a GGE basis and that there may be evidence that E85 is priced more competitively where more than one station offers E85 nearby. Table A-3 (next page) reports the portion of observations above and below E85 price parity on an energy content basis for the Minnesota observations.

Table A-1. Seasonal and Geographic Volatility Classes for Minnesota Analysis

\begin{tabular}{|c|c|c|c|c|c|}
\hline Month & Class & $\begin{array}{l}\text { Assumed } \\
\text { Ethanol } \\
\text { Content (\%) }\end{array}$ & Month & Class & $\begin{array}{l}\text { Assumed } \\
\text { Ethanol } \\
\text { Content (\%) }\end{array}$ \\
\hline Jan & 4 & 70 & Jul & 1 & 83 \\
\hline Feb & 4 & 70 & Aug & $1 / 2$ & 80 \\
\hline Mar & 4 & 70 & Sep & 2 & 80 \\
\hline Apr & $4 / 3$ & 70 & Oct & $2 / 4$ & 70 \\
\hline May & $3 / 2$ & 75 & Nov & 4 & 70 \\
\hline June & $2 / 1$ & 80 & $\mathrm{Dec}$ & 4 & 70 \\
\hline
\end{tabular}

Minimum ethanol content is assumed to be $70 \%$. Ethanol is required to contain a denaturant that commonly makes up $2 \%$ of ethanol fuel (i.e., in practice, E100 is more accurately E98). Hence, the highest ethanol content of E85 is $83 \%$. For complete details on class differences, see DOE (2016, Table 3).

\section{Illustration of Price Spikes in Figures 4 and 5}

The conversion from \$/gal to \$/GGE eliminates the price spikes present in Figure 4. Table A-2 demonstrates this effect with an illustrative example. A conversion factor of 1.30 assumes an E85 ethanol content of 70\% (DOE 2015).

Table A-2. Sample Calculation of Spread in Gasoline Gallon Equivalents

\begin{tabular}{|l|l|l|l|}
\hline E85 (\$/gal) & E10 (\$/gal) & Spread & GGE spread \\
\hline 2.10 & 3.00 & -0.90 & $(2.10 \times 1.30)-3.00=-0.27$ \\
\hline 1.10 & 2.00 & -0.90 & $(1.10 \times 1.30)-2.00=-1.57$ \\
\hline
\end{tabular}



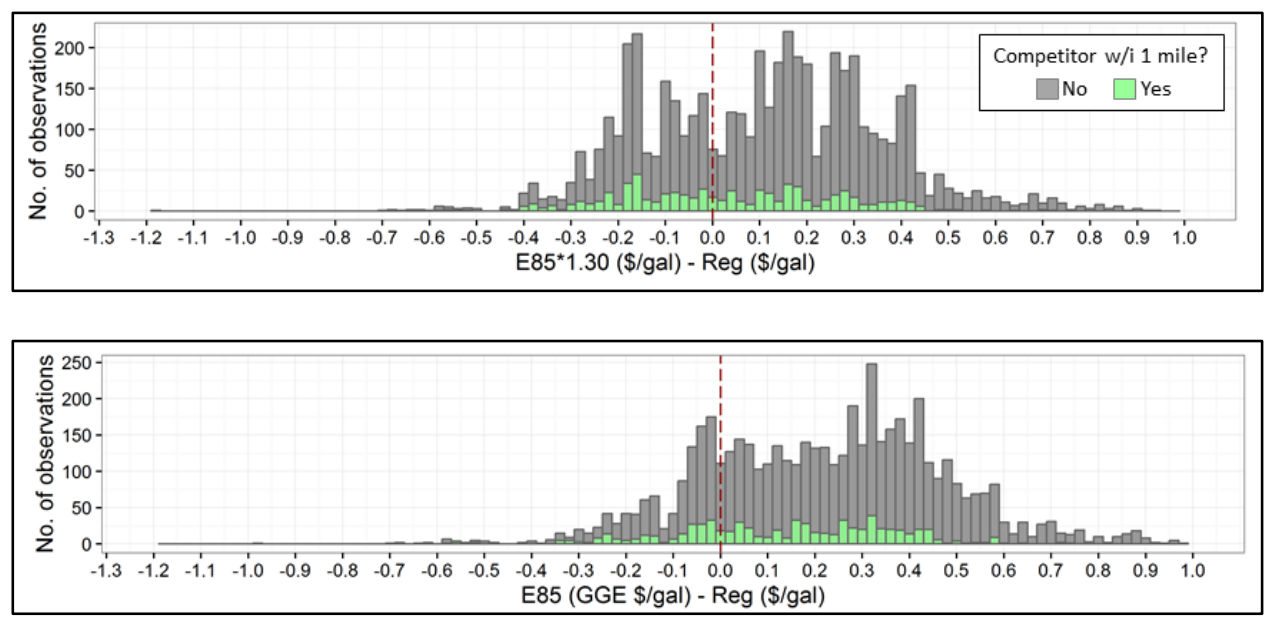

Figure A-2. Price spread in Minnesota by GGE with seasonal adjustment (top, repeated from Figure 10) and without seasonal adjustment (bottom)

Table A-3. Price Spreads in Minnesota by GGE with and without Seasonal Adjustment

\begin{tabular}{|l|l|l|l|}
\hline \multirow{2}{*}{ Spread Units } & \multirow{2}{*}{$\begin{array}{l}\text { Competitor within } \\
\text { One Mile? }\end{array}$} & \multicolumn{2}{|l|}{ Percent of Price Observations } \\
\cline { 3 - 4 } & & $\begin{array}{l}\text { E85 Less Expensive } \\
\text { than Regular }\end{array}$ & $\begin{array}{l}\text { E85 More Expensive } \\
\text { than Regular }\end{array}$ \\
\hline Figure 7: \$/gal & No & 99.7 & 0.3 \\
& Yes & 99.8 & 0.2 \\
\hline Figure 8: GGE & No & 33.7 & 66.3 \\
& Yes & 48.4 & 51.6 \\
\hline Figure 13: GGE with & No & 22.0 & 78.0 \\
seasonal adjustment & Yes & 33.1 & 66.9 \\
\hline
\end{tabular}




\section{Empirical Specification}

The analysis relies on two approaches to isolate the effect local market power on prices: crosssectional analysis (Equation 1) and within-station analysis (Equation 2):

$$
P_{E 85, i t}=\beta P_{G a s, i t}+\gamma \operatorname{Comp}_{i t}+\lambda X_{i t}+\delta_{s}+\theta_{t}+\epsilon_{i t},
$$

and

$$
P_{E 85, i t}=\beta P_{G a s, i t}+\gamma \operatorname{Comp}_{i t}+\eta_{i}+\theta_{t}+\epsilon_{i t}
$$

where

$P_{E 85, i t}$ is the reported retail price of E85 at station $i$ in time $t$

$P_{G a s, i t}$ is the reported retail price of gasoline

$\operatorname{Comp}_{i t}$ is the competition metric

$X_{i t}$ is station-level characteristics

$\delta_{s}$ is geographic fixed effects

$\theta_{t}$ is temporal fixed effects

$\eta_{i}$ is station-level fixed effects

$\epsilon_{i t}$ is the random error term

$\beta, \gamma, \lambda$ are regression coefficients.

In both specifications, the dependent variable, $P_{E 85, i t}$, is the reported retail price of E85 at station $i$ in time $t .{ }^{16}$ For the Minnesota analysis, the main specification utilizes weekly average prices (i.e., $t$ represents the week of the sample). Price observations were transformed into weekly averages in an effort to increase consistency in price reporting, address potential lag in the impact of spatial competition changes, and match the frequency of wholesale fuel price observations.

The variable of interest in both models is the competition metric, $\operatorname{Comp}_{i t}$. The competition metric was estimated in three forms:

1. Station density: A discrete measure of the number of stations within a given radius from the station at which prices are observed. Different, discrete levels of competition were selected and the empirical mode was estimated separately for each.

\footnotetext{
${ }^{16}$ One plausible specification of this model would include the retail E85-regular gas price spread as the model's dependent variable. Note that this is equivalent to constraining the coefficient on retail, regular gasoline price in both specifications above, $P_{\text {Gas, } i t}$, to one. To relax this restriction, the retail regular gasoline price enters linearly as a control variable and captures the extent to which E85 prices vary with regular gasoline prices in the retail market.
} 
2. Competitor proximity: A continuous value that represents the distance to the nearest competing station in the E85 market. ${ }^{17}$

3. Binned competitor proximity: A binned version of the discrete metric is computed, producing binary variables that indicate whether a station is subject to E85 price competition. The bins were defined as (1) within 0.1 miles, (2) between 0.1 and 0.5 miles, (3) between 0.5 and 1.0 miles, (4) between 1.0 and 2.0 miles, and (5) beyond 2.0 miles.

All other dependent variables enter the specification as controls. Observable, time variant, station-level characteristics enter the cross-sectional specification as $X_{i t}$. Cross-sectional regressions for both the national and Minnesota data include a station's distance to the nearest ethanol terminal to account for station-level variation in wholesale fuel transportation costs. Note that other station attributes for the user-reported, national data were extremely sparse and hence omitted from the specification. Data on station brand were available from the Minnesota data set and are included as controls where specified. Other station attributes for the Minnesota stations were not consistently available and were not included in the regression analysis.

The inclusion of geographic fixed effects, $\delta_{s}$, controls for time-invariant attributes at the chosen level. For example, in the national study, the inclusion of census tract fixed effects controls for differences across census tracts in attributes such as population, income, FFV penetration, and access to highway infrastructure. ${ }^{18}$ Insufficient variation in observations at the census tract level for the Minnesota analysis necessitated the use of county-level fixed effects. Temporal fixed effects, $\theta_{t}$, are included in both specifications and control for national, year-week trends, such as national variation in wholesale fuel prices or national trends in FFV purchasing and E85 use. Monthly fixed effects are used in the Minnesota data to retain available variation in rack ethanol prices.

The last term in both specifications, $\epsilon_{i t}$, represents the random error term. Error terms for both the national and Minnesota model are clustered at the county level in an effort to capture possible heterogeneity in responses to idiosyncratic shocks across counties.

\section{Results}

\section{Regression Analysis}

Results of regression analysis using all three competition metrics are included in Tables A-5 through A-10. Rows labeled "No. stations w/i x mi" correspond to the station density measure. "Dist. to nearest station" reports estimated increase in price per gallon with each additional mile of linear distance between stations (the linear proximity specification). Each "Bins" row represents coefficient estimates and standard errors for the reported proximity group. Tables A-5 and A-6 include results of the national cross-sectional and within-station analysis respectively. The remaining tables correspond to the Minnesota analysis. Tables A-9 and A-10 display results for the Minnesota analysis with user-reported RFA price observations omitted.

\footnotetext{
${ }^{17}$ This measure enters the specification linearly, though results of analysis with a non-linear (e.g., quadratic) specification do not significantly alter the study's conclusions.

${ }^{18}$ Census tracts represent 1,200 to 8,000 people. They are geographically delineated by "visible and identifiable features." (U.S. Census Bureau, "Geographic Terms and Concepts: Census Tract," https://www.census.gov/geo/reference/gtc/gtc_ct.html)
} 
Given the results across the three competition metrics as discussed in the body of this report, it is possible that entry of E85 retailers reduces market power of incumbent stations offering E85 nearby, thus lowering E85 prices. Overall, while the current data do not support a consistent statistically significant relationship between spatial competition and E85 pricing, results are indicative of an inverse relationship between station density and price (i.e., higher station density is associated with lower per-gallon prices). Better data would be necessary to draw definitive conclusions on this point. In the better-identified within-station analysis, point estimates of entry impacts are of similar magnitude to those of the cross-sectional analysis, but they are not statistically distinguishable from zero. This lack of statistical significance likely derives in part from the scarcity of consistent E85 price data. Therefore, acquisition of more comprehensive data is desirable to improve the precision of future E85 market analysis.

\section{Causal Interpretation}

Accurate, causal interpretations for cross-sectional estimations in both the national data set and the Minnesota data set rely on the assumption that the included fixed effects sufficiently control for confounding variation in the data. To interpret the results as causal (i.e., that adding one more E85 station within a X-mile radius causes a \$Y per gallon change in E85 prices), the residual variation in the dependent variable, after accounting for all controls, must only contain random variation and variation due to the level of spatial competition. If some other factor (i.e., an omitted variable) remains as variation in the error term, the coefficient estimate on the competition measure will be biased. In the analysis discussed above, much of this variation is addressed by the inclusion of spatial time-invariant fixed effects as well as national temporal fixed effects. A causal effect identified in these results could be incorrect if important variation occurs at more granular levels than the chosen fixed effects. For example, if station brand (a station-level attribute not captured in the geographic fixed effects of the cross-sectional model) varies meaningfully with E85 prices, the omission of station brand controls in the national data set could act as an omitted variable. Further, the presence of factors that vary both temporally and spatially (e.g., a local incentive program for E85 fueling) could also violate the conditions for causal interpretation as this variation is not captured by the specified fixed effects. The within-station analysis is better identified as it controls for station-level variation through the included station-level fixed effects. The shorter period of this analysis also makes significant temporal variation less likely within the month-level, time-fixed effects.

Additionally, there remains some concern of simultaneity with respect to E85 prices and station density. If high E85 prices were likely to motivate retailers to install equipment capable of offering E85, it is possible that E85 price and station density would be simultaneously determined. High-blend ethanol fuels are more corrosive than standard gasoline and therefore require upgrades of storage and dispensing infrastructure with costs in the range of $\$ 20,000$ to $\$ 60,000$, varying based on the level of upgrade or new installation (Johnson and Melendez 2007). These upgrades may take multiple weeks to complete. ${ }^{19}$ These factors support the assumption that station density and E85 prices are not contemporaneously correlated.

\footnotetext{
${ }^{19}$ For details on the steps necessary to upgrade or install new E85 equipment, see "Installing E85 Equipment" (AFDC, http://www.afdc.energy.gov/fuels/ethanol_installing_equip.html).
} 
Additionally, in the cross-sectional analysis, if greater spatial density were correlated with higher prices, our coefficient estimates would be biased toward zero and hence would be conservative. ${ }^{20}$

Lastly, given the incomplete nature of reported prices it remains possible that both the national and proprietary data sets suffer from bias due to sample selection. If the set of stations that report prices to OPIS, or the stations that have users report their prices, are in some way different from the general population of stations, our resulting estimates will be a biased estimate of firm behavior in the presence of market power. One possible way of testing this would be to compare the attributes of those stations that report prices versus those that do not; however, station attribute data remains sparse in each of the available data sets, and prices at non-reporting stations would require additional data collection.

Table A-4 is similar to Table 1, with extra t-statistics columns added. Table A-4 is referenced in Footnote 9 in the body of the text.

\footnotetext{
${ }^{20}$ See Barron et al. (2004) for additional discussion of causal interpretations, data coverage, and endogeneity in the
} context of retail fuel markets. 
Table A-4. T-Statistics for Minnesota Fuel Price Calculations

\begin{tabular}{|c|c|c|c|c|c|c|c|}
\hline & & \multirow[b]{2}{*}{$\begin{array}{l}\text { No. of } \\
\text { Stations }\end{array}$} & \multicolumn{2}{|c|}{ Fuel price } & \multicolumn{3}{|c|}{ T-statistics versus... } \\
\hline & & & Mean & Variance & $\begin{array}{l}\text { All MN Stations } \\
\text { (Row 1) }\end{array}$ & $\begin{array}{l}\text { Isolated Stations } \\
\text { (Row 2) }\end{array}$ & $\begin{array}{l}\text { Stations with Competition } \\
\text { within } 1.0 \text { Miles (Row 4) }\end{array}$ \\
\hline \multicolumn{8}{|c|}{ E85 Prices } \\
\hline 1 & MN stations & 109 & 2.59 & 0.076 & - & - & - \\
\hline 2 & Isolated stations $^{a}$ & 93 & 2.63 & 0.073 & -0.863 & - & - \\
\hline 3 & \multicolumn{4}{|c|}{ With an E85 station within ... } & - & - & - \\
\hline 4 & $\ldots 1$ mile & 16 & 2.40 & 0.053 & $3.042^{* * *}$ & $3.566^{\star * *}$ & - \\
\hline 5 & $\ldots 0.5$ miles & 7 & 2.35 & 0.041 & $2.974^{* * *}$ & $3.386^{\star * *}$ & 0.579 \\
\hline 6 & $\ldots 0.1$ miles & 2 & 2.49 & 0.072 & 0.565 & 0.739 & -0.443 \\
\hline 7 & \multicolumn{7}{|c|}{ With E85 station density change in 2014 within ... } \\
\hline 8 & .. 1 mile & 2 & 2.24 & 0.006 & $5.867^{* * *}$ & $6.421^{* * *}$ & - \\
\hline 9 & $\ldots 0.5$ miles & 1 & 2.30 & - & $11.281^{* * *}$ & $12.539^{* \star *}$ & - \\
\hline 10 & $\ldots 0.1$ miles & 1 & 2.30 & - & $11.281^{* * *}$ & $12.539^{* * *}$ & - \\
\hline \multicolumn{8}{|c|}{ Regular Gas Prices } \\
\hline 1 & MN stations & 109 & 3.24 & 0.010 & - & - & - \\
\hline 2 & Isolated stations ${ }^{\mathrm{a}}$ & 93 & 3.23 & 0.009 & 0.800 & - & - \\
\hline 3 & \multicolumn{4}{|c|}{ With an E85 station within ... } & - & - & - \\
\hline 4 & $\ldots 1$ mile & 16 & 3.21 & 0.015 & 0.790 & 0.445 & - \\
\hline 5 & $\ldots 0.5$ miles & 7 & 3.19 & 0.036 & 0.720 & 0.565 & 0.366 \\
\hline 6 & $\ldots 0.1$ miles & 2 & 3.28 & 0.008 & -0.708 & -0.881 & -1.104 \\
\hline 7 & \multicolumn{7}{|c|}{ With E85 station density change in 2014 within ... } \\
\hline 8 & $\ldots 1$ mile & 2 & 3.23 & 0.000 & 0.690 & -0.155 & - \\
\hline 9 & $\ldots 0.5$ miles & 1 & 3.22 & - & $1.875^{* *}$ & 0.720 & - \\
\hline 10 & $\ldots 0.1$ miles & 1 & 3.22 & - & $1.875^{\star *}$ & 0.720 & - \\
\hline
\end{tabular}

\footnotetext{
${ }^{a}$ Isolated stations include those without another E85 station within 1 mile.

${ }^{* * *}$ Denotes significance at the $95 \%$ level

** Denotes significance at the $90 \%$ level
} 
Table A-5. Cross-Sectional Results: National Price Change

\begin{tabular}{|c|c|c|c|c|c|c|c|}
\hline & \multicolumn{7}{|c|}{ Dependent Variable: E85 price (\$/gal) } \\
\hline & (1) & (2) & (3) & (4) & (5) & (6) & (7) \\
\hline Retail gasoline price (\$/gal) & $\begin{array}{l}0.494^{* * *} \\
(0.036)\end{array}$ & $\begin{array}{l}0.494^{* * *} \\
(0.036)\end{array}$ & $\begin{array}{l}0.494^{* * *} \\
(0.036)\end{array}$ & $\begin{array}{l}0.494^{* * *} \\
(0.036)\end{array}$ & $\begin{array}{l}0.494^{* * *} \\
(0.036)\end{array}$ & $\begin{array}{l}0.494^{* * *} \\
(0.036)\end{array}$ & $\begin{array}{l}0.494^{* * *} \\
(0.036)\end{array}$ \\
\hline No. stations w/i $0.1 \mathrm{mi}$ & $\begin{array}{l}-0.062^{* * *} \\
(0.022)\end{array}$ & & & & & & \\
\hline No. stations w/i $0.5 \mathrm{mi}$ & & $\begin{array}{l}-0.070^{* * *} \\
(0.022)\end{array}$ & & & & & \\
\hline No. stations w/i $1 \mathrm{mi}$ & & & $\begin{array}{l}-0.022 \\
(0.021)\end{array}$ & & & & \\
\hline No. stations w/i $2 \mathrm{mi}$ & & & & $\begin{array}{l}0.004 \\
(0.018)\end{array}$ & & & \\
\hline No. stations w/i 3 mi & & & & & $\begin{array}{l}-0.013 \\
(0.012)\end{array}$ & & \\
\hline Dist. to nearest station $(10 \mathrm{mi})$ & & & & & & $\begin{array}{l}0.002 \\
(0.005)\end{array}$ & \\
\hline Bin: $x \leq 0.1 \mathrm{mi}$ & & & & & & & $\begin{array}{l}-0.071^{* * *} \\
(0.022)\end{array}$ \\
\hline Bin: $0.1 \mathrm{mi}<x \leq 0.5 \mathrm{mi}$ & & & & & & & $\begin{array}{l}-0.061^{* *} \\
(0.028)\end{array}$ \\
\hline Bin: $0.5 \mathrm{mi}<x \leq 1 \mathrm{mi}$ & & & & & & & $\begin{array}{l}0.017 \\
(0.028)\end{array}$ \\
\hline Bin: $1 \mathrm{mi}<x \leq 2 \mathrm{mi}$ & & & & & & & $\begin{array}{l}0.018 \\
(0.021)\end{array}$ \\
\hline Dist. to terminal $(10 \mathrm{mi})$ & $\begin{array}{l}0.030 \\
(0.068)\end{array}$ & $\begin{array}{l}0.028 \\
(0.067)\end{array}$ & $\begin{array}{l}0.041 \\
(0.069)\end{array}$ & $\begin{array}{l}0.031 \\
(0.076)\end{array}$ & $\begin{array}{l}0.066 \\
(0.080)\end{array}$ & $\begin{array}{l}0.038 \\
(0.069)\end{array}$ & $\begin{array}{l}0.006 \\
(0.069)\end{array}$ \\
\hline Census tract FE & $\mathrm{Y}$ & $\mathrm{Y}$ & $\mathrm{Y}$ & $\mathrm{Y}$ & $\mathrm{Y}$ & $\mathrm{Y}$ & $\mathrm{Y}$ \\
\hline Week-vear FE & $\mathrm{Y}$ & $\mathrm{Y}$ & $\mathrm{Y}$ & $\mathrm{Y}$ & $\mathrm{Y}$ & $\mathrm{Y}$ & $\mathrm{Y}$ \\
\hline Observations & 38.369 & 38.369 & 38.369 & 38.369 & 38.369 & 38.369 & 38.369 \\
\hline Adiusted R-squared & 0.912 & 0.912 & 0.912 & 0.912 & 0.912 & 0.912 & 0.912 \\
\hline Residual Std. Error & 0.166 & 0.166 & 0.166 & 0.166 & 0.166 & 0.166 & 0.166 \\
\hline
\end{tabular}

Notes: $\mathrm{mi}=$ miles. ${ }^{*} p<0.1 ;{ }^{* *} p<0.05 ;{ }^{* *} p<0.01$. Standard errors clustered at the county level. Omitted bin is nearest station outside of 2 miles. 
Table A-6. Cross-Sectional Results: National Percent Change

\begin{tabular}{|c|c|c|c|c|c|c|c|}
\hline & \multicolumn{7}{|c|}{ Dependent Variable: log E85 price (\$/gal) } \\
\hline & (1) & $(2)$ & (3) & (4) & (5) & (6) & (7) \\
\hline Log of retail gasoline price (\$/gal) & $\begin{array}{l}0.618^{* * *} \\
(0.066)\end{array}$ & $\begin{array}{l}0.618^{* * *} \\
(0.066)\end{array}$ & $\begin{array}{l}0.618^{* * *} \\
(0.066)\end{array}$ & $\begin{array}{l}0.618 * * * \\
(0.066)\end{array}$ & $\begin{array}{l}0.617^{* * *} \\
(0.066)\end{array}$ & $\begin{array}{l}0.618 * * * \\
(0.066)\end{array}$ & $\begin{array}{l}0.617^{* * *} \\
(0.066)\end{array}$ \\
\hline No. stations w/i $0.1 \mathrm{mi}$ & $\begin{array}{l}-0.020^{* * *} \\
(0.007)\end{array}$ & & & & & & \\
\hline No. stations w/i $0.5 \mathrm{mi}$ & & $\begin{array}{l}-0.029^{* * *} \\
(0.009)\end{array}$ & & & & & \\
\hline No. stations w/i 1 mi & & & $\begin{array}{l}-0.013^{*} \\
(0.008)\end{array}$ & & & & \\
\hline No. stations w/i 2 mi & & & & $\begin{array}{l}0.003 \\
(0.008)\end{array}$ & & & \\
\hline No. stations w/i 3 mi & & & & & $\begin{array}{l}-0.004 \\
(0.005)\end{array}$ & & \\
\hline Dist. to nearest station (10 mi) & & & & & & $\begin{array}{l}0.001 \\
(0.002)\end{array}$ & \\
\hline Bin: $x \leq 0.1 \mathrm{mi}$ & & & & & & & $\begin{array}{l}-0.025^{* * *} \\
(0.008)\end{array}$ \\
\hline Bin: $0.1 \mathrm{mi}<x \leq 0.5 \mathrm{mi}$ & & & & & & & $\begin{array}{l}-0.028^{* *} \\
(0.012)\end{array}$ \\
\hline Bin: $0.5 \mathrm{mi}<x \leq 1 \mathrm{mi}$ & & & & & & & $\begin{array}{l}0.0005 \\
(0.011)\end{array}$ \\
\hline Bin: $1 \mathrm{mi}<x \leq 2 \mathrm{mi}$ & & & & & & & $\begin{array}{l}0.012 \\
(0.008)\end{array}$ \\
\hline Dist. to terminal (10 mi) & $\begin{array}{l}0.021 \\
(0.031)\end{array}$ & $\begin{array}{l}0.020 \\
(0.031)\end{array}$ & $\begin{array}{l}0.026 \\
(0.031)\end{array}$ & $\begin{array}{l}0.020 \\
(0.032)\end{array}$ & $\begin{array}{l}0.032 \\
(0.034)\end{array}$ & $\begin{array}{l}0.024 \\
(0.031)\end{array}$ & $\begin{array}{l}0.009 \\
(0.028)\end{array}$ \\
\hline Census tract FE & $\mathrm{Y}$ & $\mathrm{Y}$ & $\mathrm{Y}$ & $\mathrm{Y}$ & $\mathrm{Y}$ & $\mathrm{Y}$ & $\mathrm{Y}$ \\
\hline Week-year FE & Y & Y & Y & Y & Y & Y & Y \\
\hline Observations & 38,369 & 38,369 & 38,369 & 38,369 & 38,369 & 38,369 & 38,369 \\
\hline Adjusted R-squared & 0.905 & 0.905 & 0.905 & 0.905 & 0.905 & 0.905 & 0.905 \\
\hline Residual Std. Error & 0.071 & 0.071 & 0.071 & 0.071 & 0.071 & 0.071 & 0.071 \\
\hline
\end{tabular}

Notes: $\mathrm{mi}=$ miles. ${ }^{*} \mathrm{p}<0.1 ;{ }^{* *} p<0.05 ;{ }^{* *} p<0.01$. Standard errors clustered at the county level. Omitted bin is nearest station outside of 2 miles. 
Table A-7. Within-Station Results: National Price Change

\begin{tabular}{|c|c|c|c|c|c|c|c|}
\hline & \multicolumn{7}{|c|}{ Dependent Variable: E85 price (\$/gal) } \\
\hline & (1) & $(2)$ & (3) & (4) & (5) & (6) & (7) \\
\hline Retail gasoline price (\$/gal) & $\begin{array}{l}0.495^{* * *} \\
(0.036)\end{array}$ & $\begin{array}{l}0.495^{* * *} \\
(0.036)\end{array}$ & $\begin{array}{l}0.495^{* * *} \\
(0.036)\end{array}$ & $\begin{array}{l}0.495^{* * *} \\
(0.036)\end{array}$ & $\begin{array}{l}0.495^{* * *} \\
(0.036)\end{array}$ & $\begin{array}{l}0.495^{* * *} \\
(0.036)\end{array}$ & $\begin{array}{l}0.495^{* * *} \\
(0.036)\end{array}$ \\
\hline No. stations w/i $0.1 \mathrm{mi}$ & $\begin{array}{l}-0.030 \\
(0.053)\end{array}$ & & & & & & \\
\hline No. stations w/i $0.5 \mathrm{mi}$ & & $\begin{array}{l}-0.043 \\
(0.028)\end{array}$ & & & & & \\
\hline No. stations w/i $1 \mathrm{mi}$ & & & $\begin{array}{l}-0.012 \\
(0.023)\end{array}$ & & & & \\
\hline No. stations w/i 2 mi & & & & $\begin{array}{l}0.003 \\
(0.019)\end{array}$ & & & \\
\hline No. stations w/i 3 mi & & & & & $\begin{array}{l}-0.017 \\
(0.013)\end{array}$ & & \\
\hline Dist. to nearest station (10 mi) & & & & & & $\begin{array}{l}0.002 \\
(0.005)\end{array}$ & \\
\hline Bin: $x \leq 0.1 \mathrm{mi}$ & & & & & & & $\begin{array}{l}-0.027 \\
(0.053)\end{array}$ \\
\hline Bin: $0.1 \mathrm{mi}<x \leq 0.5 \mathrm{mi}$ & & & & & & & $\begin{array}{l}-0.047 \\
(0.035)\end{array}$ \\
\hline Bin: $0.5 \mathrm{mi}<x \leq 1 \mathrm{mi}$ & & & & & & & $\begin{array}{l}0.017 \\
(0.029)\end{array}$ \\
\hline Bin: $1 \mathrm{mi}<x \leq 2 \mathrm{mi}$ & & & & & & & $\begin{array}{l}0.015 \\
(0.023)\end{array}$ \\
\hline Station FE & $\mathrm{Y}$ & $\mathrm{Y}$ & $\mathrm{Y}$ & $\mathrm{Y}$ & $\mathrm{Y}$ & $\mathrm{Y}$ & $\mathrm{Y}$ \\
\hline Week-vear FE & $\mathrm{Y}$ & $\mathrm{Y}$ & $\mathrm{Y}$ & $\mathrm{Y}$ & $\mathrm{Y}$ & $\mathrm{Y}$ & $\mathrm{Y}$ \\
\hline Observations & 38.369 & 38.369 & 38.369 & 38.369 & 38.369 & 38.369 & 38.369 \\
\hline Adiusted R-squared & 0.912 & 0.912 & 0.912 & 0.912 & 0.912 & 0.912 & 0.912 \\
\hline Residual Std. Error & 0.166 & 0.166 & 0.166 & 0.166 & 0.166 & 0.166 & 0.166 \\
\hline
\end{tabular}

Notes: $\mathrm{mi}=$ miles. $* p<0.1 ; * * p<0.05 ; * * * p<0.01$. Standard errors clustered at the county level. Omitted bin is nearest station outside of 2 miles. 
Table A-8. Within-Station Results: National Percent Change

Dependent Variable: log of E85 price (\$/gal)

\begin{tabular}{|c|c|c|c|c|c|c|c|}
\hline & \multicolumn{7}{|c|}{ Dependent Variable: log of E85 price (\$/gal) } \\
\hline & (1) & (2) & (3) & (4) & (5) & (6) & (7) \\
\hline Log of retail gasoline price (\$/gal) & $\begin{array}{l}0.618^{* * *} \\
(0.067)\end{array}$ & $\begin{array}{l}0.618^{* * *} \\
(0.067)\end{array}$ & $\begin{array}{l}0.618^{* * *} \\
(0.067)\end{array}$ & $\begin{array}{l}0.618^{* * *} \\
(0.067)\end{array}$ & $\begin{array}{l}0.618^{* * *} \\
(0.067)\end{array}$ & $\begin{array}{l}0.618^{* * *} \\
(0.067)\end{array}$ & $\begin{array}{l}0.618^{* * *} \\
(0.067)\end{array}$ \\
\hline No. stations w/i $0.1 \mathrm{mi}$ & $\begin{array}{l}-0.007 \\
(0.018)\end{array}$ & & & & & & \\
\hline No. stations w/i $0.5 \mathrm{mi}$ & & $\begin{array}{l}-0.022^{*} \\
(0.012)\end{array}$ & & & & & \\
\hline No. stations w/i $1 \mathrm{mi}$ & & & $\begin{array}{l}-0.010 \\
(0.008)\end{array}$ & & & & \\
\hline No. stations w/i 2 mi & & & & $\begin{array}{l}0.002 \\
(0.008)\end{array}$ & & & \\
\hline No. stations w/i $3 \mathrm{mi}$ & & & & & $\begin{array}{l}-0.006 \\
(0.005)\end{array}$ & & \\
\hline Dist. to nearest station (10 mi) & & & & & & $\begin{array}{l}0.001 \\
(0.002)\end{array}$ & \\
\hline Bin: $x \leq 0.1 \mathrm{mi}$ & & & & & & & $\begin{array}{l}-0.007 \\
(0.018)\end{array}$ \\
\hline Bin: $0.1 \mathrm{mi}<x \leq 0.5 \mathrm{mi}$ & & & & & & & $\begin{array}{l}-0.030^{*} \\
(0.016)\end{array}$ \\
\hline Bin: $0.5 \mathrm{mi}<x \leq 1 \mathrm{mi}$ & & & & & & & $\begin{array}{l}0.0001 \\
(0.012)\end{array}$ \\
\hline Bin: $1 \mathrm{mi}<\mathrm{x} \leq 2 \mathrm{mi}$ & & & & & & & $\begin{array}{c}0.010 \\
(0.009)\end{array}$ \\
\hline Station FE & $\mathrm{Y}$ & $\mathrm{Y}$ & $\mathrm{Y}$ & $\mathrm{Y}$ & $\mathrm{Y}$ & $\mathrm{Y}$ & $\mathrm{Y}$ \\
\hline Week-year FE & $\mathrm{Y}$ & $\mathrm{Y}$ & $\mathrm{Y}$ & $\mathrm{Y}$ & $\mathrm{Y}$ & $\mathrm{Y}$ & $\mathrm{Y}$ \\
\hline Observations & 38,369 & 38,369 & 38,369 & 38,369 & 38,369 & 38,369 & 38,369 \\
\hline Adjusted R-squared & 0.905 & 0.905 & 0.905 & 0.905 & 0.905 & 0.905 & 0.905 \\
\hline Residual Std. Error & 0.070 & 0.070 & 0.070 & 0.070 & 0.070 & 0.070 & 0.070 \\
\hline
\end{tabular}

Notes: $\mathrm{mi}=$ miles. ${ }^{*} \mathrm{p}<0.1 ;{ }^{* *} p<0.05 ;{ }^{* * *} p<0.01$. Standard errors clustered at the county level. Omitted bin is nearest station outside of 2 miles. 
Table A-9. Cross-Sectional Results: Minnesota Price Change

\begin{tabular}{|c|c|c|c|c|c|c|c|}
\hline & \multicolumn{7}{|c|}{ Dependent Variable: E85 price (\$/gal) } \\
\hline & (1) & (2) & (3) & (4) & (5) & (6) & (7) \\
\hline Retail gasoline price (\$/gal) & $\begin{array}{l}0.389^{* * *} \\
(0.050)\end{array}$ & $\begin{array}{l}0.390 * * * \\
(0.050)\end{array}$ & $\begin{array}{l}0.388^{* * *} \\
(0.050)\end{array}$ & $\begin{array}{l}0.394^{* * *} \\
(0.048)\end{array}$ & $\begin{array}{l}0.392^{* * *} \\
(0.053)\end{array}$ & $\begin{array}{l}0.392^{* * *} \\
(0.050)\end{array}$ & $\begin{array}{l}0.392^{* * *} \\
(0.044)\end{array}$ \\
\hline Rack ethanol price (\$/gal) & $\begin{array}{l}0.158^{* * *} \\
(0.026)\end{array}$ & $\begin{array}{l}0.158^{* * *} \\
(0.026)\end{array}$ & $\begin{array}{l}0.158^{* * *} \\
(0.026)\end{array}$ & $\begin{array}{l}0.158^{* * *} \\
(0.025)\end{array}$ & $\begin{array}{l}0.158^{* * *} \\
(0.025)\end{array}$ & $\begin{array}{l}0.158^{* * *} \\
(0.025)\end{array}$ & $\begin{array}{l}0.158^{* * *} \\
(0.026)\end{array}$ \\
\hline No. stations w/i $0.1 \mathrm{mi}$ & $\begin{array}{l}-0.039 * * \\
(0.017)\end{array}$ & & & & & & \\
\hline No. stations w/i $0.5 \mathrm{mi}$ & & $\begin{array}{l}-0.019 \\
(0.022)\end{array}$ & & & & & \\
\hline No. stations w/i 1 mi & & & $\begin{array}{l}-0.033^{* *} \\
(0.017)\end{array}$ & & & & \\
\hline No. stations w/i 2 mi & & & & $\begin{array}{l}-0.013 \\
(0.010)\end{array}$ & & & \\
\hline No. stations w/i 3 mi & & & & & $\begin{array}{l}0.004 \\
(0.008)\end{array}$ & & \\
\hline Dist. to nearest station (10 mi) & & & & & & $\begin{array}{l}0.044 \\
(0.071)\end{array}$ & \\
\hline Bin: $x \leq 0.1 \mathrm{mi}$ & & & & & & & $\begin{array}{l}-0.040^{* *} \\
(0.017)\end{array}$ \\
\hline Bin: $0.1 \mathrm{mi}<x \leq 0.5 \mathrm{mi}$ & & & & & & & $\begin{array}{l}-0.008 \\
(0.043)\end{array}$ \\
\hline Bin: $0.5 \mathrm{mi}<x \leq 1 \mathrm{mi}$ & & & & & & & $\begin{array}{l}-0.049^{* *} \\
(0.025)\end{array}$ \\
\hline Bin: $1 \mathrm{mi}<x \leq 2 \mathrm{mi}$ & & & & & & & $\begin{array}{l}-0.029 \\
(0.023)\end{array}$ \\
\hline Dist. to terminal (10 mi) & $\begin{array}{l}0.005 \\
(0.028)\end{array}$ & $\begin{array}{l}0.003 \\
(0.027)\end{array}$ & $\begin{array}{l}0.006 \\
(0.026)\end{array}$ & $\begin{array}{l}0.0005 \\
(0.028)\end{array}$ & $\begin{array}{l}0.004 \\
(0.029)\end{array}$ & $\begin{array}{l}0.002 \\
(0.028)\end{array}$ & $\begin{array}{l}0.004 \\
(0.028)\end{array}$ \\
\hline Countv FE & $\mathrm{Y}$ & $\mathrm{Y}$ & $\mathrm{Y}$ & $\mathrm{Y}$ & $\mathrm{Y}$ & $\mathrm{Y}$ & $\mathrm{Y}$ \\
\hline Month FE & $\mathrm{Y}$ & $\mathrm{Y}$ & $\mathrm{Y}$ & $\mathrm{Y}$ & $\mathrm{Y}$ & $\mathrm{Y}$ & $\mathrm{Y}$ \\
\hline Observations & 2.133 & 2.133 & 2.133 & 2.133 & 2.133 & 2.133 & 2.133 \\
\hline Adiusted R-squared & 0.862 & 0.862 & 0.862 & 0.862 & 0.862 & 0.862 & 0.863 \\
\hline Residual Std. Error & 0.118 & 0.118 & 0.118 & 0.118 & 0.118 & 0.118 & 0.118 \\
\hline
\end{tabular}

Notes: $\mathrm{mi}=$ miles. ${ }^{*} p<0.1 ;{ }^{* *} p<0.05 ;{ }^{* * *} p<0.01$. Standard errors clustered at the county level. Omitted bin is nearest station outside of 2 miles. 
Table A-10. Cross-Sectional Results: Minnesota Percent Change

Dependent Variable: log of E85 price (\$/gal)

\begin{tabular}{|c|c|c|c|c|c|c|c|}
\hline & \multicolumn{7}{|c|}{ Dependent Variable: log of E85 price (\$/gal) } \\
\hline & (1) & (2) & (3) & (4) & (5) & (6) & (7) \\
\hline Log retail gasoline price (\$/gal) & $\begin{array}{l}0.522 * * * \\
(0.066)\end{array}$ & $\begin{array}{l}0.524^{* * *} \\
(0.066)\end{array}$ & $\begin{array}{l}0.520 * * * \\
(0.065)\end{array}$ & $\begin{array}{l}0.525^{* * *} \\
(0.064)\end{array}$ & $\begin{array}{l}0.524 * * * \\
(0.067)\end{array}$ & $\begin{array}{l}0.525^{* * *} \\
(0.065)\end{array}$ & $\begin{array}{l}0.526 * * * \\
(0.061)\end{array}$ \\
\hline Log rack ethanol price (\$/gal) & $\begin{array}{l}0.171^{* * *} \\
(0.030)\end{array}$ & $\begin{array}{l}0.171^{* * *} \\
(0.030)\end{array}$ & $\begin{array}{l}0.171^{* * *} \\
(0.030)\end{array}$ & $\begin{array}{l}0.171^{* * *} \\
(0.030)\end{array}$ & $\begin{array}{l}0.171^{* * *} \\
(0.030)\end{array}$ & $\begin{array}{l}0.171^{* * *} \\
(0.030)\end{array}$ & $\begin{array}{l}0.171^{* * *} \\
(0.030)\end{array}$ \\
\hline No. stations w/i $0.1 \mathrm{mi}$ & $\begin{array}{l}-0.007 \\
(0.007)\end{array}$ & & & & & & \\
\hline No. stations w/i $0.5 \mathrm{mi}$ & & $\begin{array}{l}-0.001 \\
(0.008)\end{array}$ & & & & & \\
\hline No. stations w/i 1 mi & & & $\begin{array}{l}-0.012^{*} \\
(0.006)\end{array}$ & & & & \\
\hline No. stations w/i 2 mi & & & & $\begin{array}{l}-0.005 \\
(0.004)\end{array}$ & & & \\
\hline No. stations w/i 3 mi & & & & & $\begin{array}{l}0.002 \\
(0.003)\end{array}$ & & \\
\hline Dist. to nearest station (10 mi) & & & & & & $\begin{array}{l}0.025 \\
(0.035)\end{array}$ & \\
\hline Bin: $x \leq 0.1 \mathrm{mi}$ & & & & & & & $\begin{array}{l}-0.007 \\
(0.007)\end{array}$ \\
\hline Bin: $0.1 \mathrm{mi}<x \leq 0.5 \mathrm{mi}$ & & & & & & & $\begin{array}{l}0.00001 \\
(0.017)\end{array}$ \\
\hline Bin: $0.5 \mathrm{mi}<x \leq 1 \mathrm{mi}$ & & & & & & & $\begin{array}{l}-0.020^{* *} \\
(0.010)\end{array}$ \\
\hline Bin: $1 \mathrm{mi}<x \leq 2 \mathrm{mi}$ & & & & & & & $\begin{array}{l}-0.011 \\
(0.008)\end{array}$ \\
\hline Dist. to terminal (10 mi) & $\begin{array}{l}0.002 \\
(0.011)\end{array}$ & $\begin{array}{l}0.001 \\
(0.011)\end{array}$ & $\begin{array}{l}0.003 \\
(0.010)\end{array}$ & $\begin{array}{l}0.001 \\
(0.011)\end{array}$ & $\begin{array}{l}0.002 \\
(0.011)\end{array}$ & $\begin{array}{l}0.001 \\
(0.012)\end{array}$ & $\begin{array}{l}0.002 \\
(0.011)\end{array}$ \\
\hline County FE & $\mathrm{Y}$ & Y & $\mathrm{Y}$ & $\mathrm{Y}$ & $\mathrm{Y}$ & $\mathrm{Y}$ & $\mathrm{Y}$ \\
\hline Month FE & $\mathrm{Y}$ & $\mathrm{Y}$ & $\mathrm{Y}$ & Y & $\mathrm{Y}$ & Y & $\mathrm{Y}$ \\
\hline Observations & 2,133 & 2,133 & 2,133 & 2,133 & 2,133 & 2,133 & 2,133 \\
\hline Adjusted R-squared & 0.849 & 0.849 & 0.849 & 0.849 & 0.849 & 0.849 & 0.850 \\
\hline Residual Std. Error & 0.051 & 0.051 & 0.051 & 0.051 & 0.051 & 0.051 & 0.051 \\
\hline
\end{tabular}

Notes: $\mathrm{mi}=$ miles. ${ }^{*} \mathrm{p}<0.1 ;{ }^{* *} \mathrm{p}<0.05 ;{ }^{* * *} \mathrm{p}<0.01$. Standard errors clustered at the county level. Omitted bin is nearest station outside of 2 miles. 
Table A-11. Cross-Sectional Results: Minnesota Price Change with Brand Controls

\begin{tabular}{|c|c|c|c|c|c|c|c|}
\hline & \multicolumn{7}{|c|}{ Dependent Variable: E85 price (\$/gal) } \\
\hline & (1) & (2) & (3) & (4) & (5) & (6) & (7) \\
\hline Retail gasoline price (\$/gal) & $\begin{array}{l}0.411^{* * *} \\
(0.039)\end{array}$ & $\begin{array}{l}0.412^{* * *} \\
(0.040)\end{array}$ & $\begin{array}{l}0.409^{* * *} \\
(0.040)\end{array}$ & $\begin{array}{l}0.413^{* * *} \\
(0.041)\end{array}$ & $\begin{array}{l}0.414^{* * *} \\
(0.042)\end{array}$ & $\begin{array}{l}0.413^{* * *} \\
(0.040)\end{array}$ & $\begin{array}{l}0.409 * * * \\
(0.039)\end{array}$ \\
\hline Rack ethanol price (\$/gal) & $\begin{array}{l}0.160^{* * *} \\
(0.026)\end{array}$ & $\begin{array}{l}0.160^{* * *} \\
(0.026)\end{array}$ & $\begin{array}{l}0.160^{* * *} \\
(0.026)\end{array}$ & $\begin{array}{l}0.160^{* * *} \\
(0.026)\end{array}$ & $\begin{array}{l}0.160^{* * *} \\
(0.026)\end{array}$ & $\begin{array}{l}0.160^{* * *} \\
(0.026)\end{array}$ & $\begin{array}{l}0.160^{* * *} \\
(0.026)\end{array}$ \\
\hline No. stations w/i $0.1 \mathrm{mi}$ & $\begin{array}{l}-0.038^{* * *} \\
(0.011)\end{array}$ & & & & & & \\
\hline No. stations w/i $0.5 \mathrm{mi}$ & & $\begin{array}{l}-0.018 \\
(0.020)\end{array}$ & & & & & \\
\hline No. stations w/i $1 \mathrm{mi}$ & & & $\begin{array}{l}-0.027^{*} \\
(0.016)\end{array}$ & & & & \\
\hline No. stations w/i $2 \mathrm{mi}$ & & & & $\begin{array}{l}-0.010 \\
(0.008)\end{array}$ & & & \\
\hline No. stations w/i $3 \mathrm{mi}$ & & & & & $\begin{array}{l}0.002 \\
(0.005)\end{array}$ & & \\
\hline Dist. to nearest station (10 mi) & & & & & & $\begin{array}{l}0.072 \\
(0.064)\end{array}$ & \\
\hline Bin: $x \leq 0.1 \mathrm{mi}$ & & & & & & & $\begin{array}{l}-0.038^{* * *} \\
(0.012)\end{array}$ \\
\hline Bin: $0.1 \mathrm{mi}<x \leq 0.5 \mathrm{mi}$ & & & & & & & $\begin{array}{l}0.020 \\
(0.027)\end{array}$ \\
\hline Bin: $0.5 \mathrm{mi}<x \leq 1 \mathrm{mi}$ & & & & & & & $\begin{array}{l}-0.032 \\
(0.021)\end{array}$ \\
\hline Bin: $1 \mathrm{mi}<x \leq 2 \mathrm{mi}$ & & & & & & & $\begin{array}{l}-0.014 \\
(0.009)\end{array}$ \\
\hline Dist. to terminal (10 mi) & $\begin{array}{l}0.004 \\
(0.018)\end{array}$ & $\begin{array}{l}0.002 \\
(0.018)\end{array}$ & $\begin{array}{l}0.004 \\
(0.018)\end{array}$ & $\begin{array}{l}-0.001 \\
(0.018)\end{array}$ & $\begin{array}{l}0.002 \\
(0.020)\end{array}$ & $\begin{array}{l}0.002 \\
(0.020)\end{array}$ & $\begin{array}{l}0.003 \\
(0.018)\end{array}$ \\
\hline Brand: Cenex & $\begin{array}{l}0.054 \\
(0.079)\end{array}$ & $\begin{array}{l}0.060 \\
(0.080)\end{array}$ & $\begin{array}{l}0.059 \\
(0.077)\end{array}$ & $\begin{array}{l}0.072 \\
(0.081)\end{array}$ & $\begin{array}{l}0.053 \\
(0.079)\end{array}$ & $\begin{array}{l}0.076 \\
(0.090)\end{array}$ & $\begin{array}{l}0.063 \\
(0.081)\end{array}$ \\
\hline Brand: Freedom & $\begin{array}{l}0.053^{* *} \\
(0.024)\end{array}$ & $\begin{array}{l}0.052^{* *} \\
(0.024)\end{array}$ & $\begin{array}{l}0.065^{* *} \\
(0.031)\end{array}$ & $\begin{array}{l}0.055^{* *} \\
(0.024)\end{array}$ & $\begin{array}{l}0.050 * * \\
(0.025)\end{array}$ & $\begin{array}{l}0.096 * * \\
(0.047)\end{array}$ & $\begin{array}{l}0.065^{* *} \\
(0.030)\end{array}$ \\
\hline Brand: Holiday & $\begin{array}{l}-0.013 \\
(0.024)\end{array}$ & $\begin{array}{l}-0.014 \\
(0.023)\end{array}$ & $\begin{array}{l}0.003 \\
(0.031)\end{array}$ & $\begin{array}{l}-0.002 \\
(0.026)\end{array}$ & $\begin{array}{l}-0.017 \\
(0.024)\end{array}$ & $\begin{array}{l}0.030 \\
(0.049)\end{array}$ & $\begin{array}{l}0.011 \\
(0.034)\end{array}$ \\
\hline Brand: Kwik Trip & $\begin{array}{l}0.134^{* * *} \\
(0.023)\end{array}$ & $\begin{array}{l}0.134^{* * *} \\
(0.022)\end{array}$ & $\begin{array}{l}0.143^{* * *} \\
(0.029)\end{array}$ & $\begin{array}{l}0.139 * * * \\
(0.025)\end{array}$ & $\begin{array}{l}0.130 * * * \\
(0.022)\end{array}$ & $\begin{array}{l}0.168^{* * *} \\
(0.041)\end{array}$ & $\begin{array}{l}0.145^{* * *} \\
(0.030)\end{array}$ \\
\hline
\end{tabular}




\begin{tabular}{lcccccccc}
\hline & \multicolumn{7}{c}{ Dependent Variable: E85 price (\$/gal) } \\
\cline { 2 - 8 } & $\mathbf{( 1 )}$ & $\mathbf{( 2 )}$ & $\mathbf{( 3 )}$ & $\mathbf{( 4 )}$ & $\mathbf{( 5 )}$ & $\mathbf{( 6 )}$ & $\mathbf{( 7 )}$ \\
\hline Brand: SuperAmerica & $0.173^{* *}$ & $0.174^{* *}$ & $0.188^{* *}$ & $0.193^{* *}$ & $0.171^{* *}$ & $0.219^{* *}$ & $0.197^{* *}$ \\
& $(0.082)$ & $(0.082)$ & $(0.082)$ & $(0.084)$ & $(0.082)$ & $(0.090)$ & $(0.083)$ \\
Brand: Other & $0.131^{*}$ & $0.132^{* *}$ & $0.146^{* *}$ & $0.151^{* *}$ & $0.130^{*}$ & $0.173^{* *}$ & $0.156^{* *}$ \\
& $(0.067)$ & $(0.067)$ & $(0.068)$ & $(0.070)$ & $(0.068)$ & $(0.080)$ & $(0.069)$ \\
\hline Countv FE & $\mathrm{Y}$ & $\mathrm{Y}$ & $\mathrm{Y}$ & $\mathrm{Y}$ & $\mathrm{Y}$ & $\mathrm{Y}$ & $\mathrm{Y}$ \\
Month FE & $\mathrm{Y}$ & $\mathrm{Y}$ & $\mathrm{Y}$ & $\mathrm{Y}$ & $\mathrm{Y}$ & $\mathrm{Y}$ & $\mathrm{Y}$ \\
Observations & 2.133 & 2.133 & 2.133 & 2.133 & 2.133 & 2.133 & 2.133 \\
Adiusted R-squared & 0.871 & 0.871 & 0.871 & 0.871 & 0.871 & 0.871 & 0.871 \\
Residual Std. Error & 0.114 & 0.114 & 0.114 & 0.114 & 0.114 & 0.114 & 0.114 \\
\hline
\end{tabular}

Notes: $\mathrm{mi}=$ miles. $* \mathrm{p}<0.1 ; * * \mathrm{p}<0.05 ; * * * \mathrm{p}<0.01$. Standard errors clustered at the county level. Omitted bin is nearest station outside of 2 miles. Unbranded stations are the omitted brand category. 
Table A-12. Cross-Sectional Results: Minnesota Percent Change with Brand Controls

Dependent Variable: log of E85 price (\$/gal)

\begin{tabular}{|c|c|c|c|c|c|c|c|}
\hline & \multicolumn{7}{|c|}{ Dependent Variable: log of E85 price (\$/gal) } \\
\hline & (1) & $(2)$ & (3) & (4) & (5) & $(6)$ & $(7)$ \\
\hline Log retail gasoline price (\$/gal) & $\begin{array}{l}0.542^{* * *} \\
(0.056)\end{array}$ & $\begin{array}{l}0.544^{* * *} \\
(0.057)\end{array}$ & $\begin{array}{l}0.539 * * * \\
(0.056)\end{array}$ & $\begin{array}{l}0.543^{* * *} \\
(0.056)\end{array}$ & $\begin{array}{l}0.544^{* * *} \\
(0.057)\end{array}$ & $\begin{array}{l}0.544^{* * *} \\
(0.055)\end{array}$ & $\begin{array}{l}0.540 * * * \\
(0.056)\end{array}$ \\
\hline Log rack ethanol price (\$/gal) & $\begin{array}{l}0.172^{* * *} \\
(0.031)\end{array}$ & $\begin{array}{l}0.172^{* * *} \\
(0.031)\end{array}$ & $\begin{array}{l}0.172^{* * *} \\
(0.031)\end{array}$ & $\begin{array}{l}0.172^{* * *} \\
(0.031)\end{array}$ & $\begin{array}{l}0.172^{* * *} \\
(0.031)\end{array}$ & $\begin{array}{l}0.172^{* * *} \\
(0.031)\end{array}$ & $\begin{array}{l}0.171^{* * *} \\
(0.031)\end{array}$ \\
\hline No. stations w/i $0.1 \mathrm{mi}$ & $\begin{array}{l}-0.007 \\
(0.004)\end{array}$ & & & & & & \\
\hline No. stations w/i $0.5 \mathrm{mi}$ & & $\begin{array}{l}0.0002 \\
(0.007)\end{array}$ & & & & & \\
\hline No. stations w/i $1 \mathrm{mi}$ & & & $\begin{array}{l}-0.009 \\
(0.006)\end{array}$ & & & & \\
\hline No. stations w/i 2 mi & & & & $\begin{array}{l}-0.003 \\
(0.003)\end{array}$ & & & \\
\hline No. stations w/i $3 \mathrm{mi}$ & & & & & $\begin{array}{l}0.001 \\
(0.002)\end{array}$ & & \\
\hline Dist. to nearest station (10 mi) & & & & & & $\begin{array}{l}0.037 \\
(0.036)\end{array}$ & \\
\hline Bin: $x \leq 0.1 \mathrm{mi}$ & & & & & & & $\begin{array}{l}-0.007 \\
(0.005)\end{array}$ \\
\hline Bin: $0.1 \mathrm{mi}<x \leq 0.5 \mathrm{mi}$ & & & & & & & $\begin{array}{l}0.011 \\
(0.012)\end{array}$ \\
\hline Bin: $0.5 \mathrm{mi}<x \leq 1 \mathrm{mi}$ & & & & & & & $\begin{array}{l}-0.013 \\
(0.009)\end{array}$ \\
\hline Bin: $1 \mathrm{mi}<x \leq 2 \mathrm{mi}$ & & & & & & & $\begin{array}{l}-0.005 \\
(0.004)\end{array}$ \\
\hline Dist. to terminal (10 mi) & $\begin{array}{l}0.001 \\
(0.007)\end{array}$ & $\begin{array}{l}0.001 \\
(0.007)\end{array}$ & $\begin{array}{l}0.002 \\
(0.007)\end{array}$ & $\begin{array}{l}0.0001 \\
(0.007)\end{array}$ & $\begin{array}{l}0.001 \\
(0.007)\end{array}$ & $\begin{array}{l}0.001 \\
(0.008)\end{array}$ & $\begin{array}{l}0.001 \\
(0.007)\end{array}$ \\
\hline Brand: Cenex & $\begin{array}{l}0.027 \\
(0.034)\end{array}$ & $\begin{array}{l}0.027 \\
(0.034)\end{array}$ & $\begin{array}{l}0.028 \\
(0.034)\end{array}$ & $\begin{array}{l}0.032 \\
(0.035)\end{array}$ & $\begin{array}{l}0.025 \\
(0.034)\end{array}$ & $\begin{array}{l}0.037 \\
(0.041)\end{array}$ & $\begin{array}{l}0.029 \\
(0.035)\end{array}$ \\
\hline Brand: Freedom & $\begin{array}{l}0.019 * \\
(0.011)\end{array}$ & $\begin{array}{l}0.018^{*} \\
(0.011)\end{array}$ & $\begin{array}{l}0.023^{*} \\
(0.014)\end{array}$ & $\begin{array}{l}0.019 * \\
(0.011)\end{array}$ & $\begin{array}{l}0.017 \\
(0.011)\end{array}$ & $\begin{array}{l}0.041^{*} \\
(0.025)\end{array}$ & $\begin{array}{l}0.024^{*} \\
(0.014)\end{array}$ \\
\hline Brand: Holiday & $\begin{array}{l}-0.005 \\
(0.011)\end{array}$ & $\begin{array}{l}-0.005 \\
(0.011)\end{array}$ & $\begin{array}{l}0.0004 \\
(0.014)\end{array}$ & $\begin{array}{l}-0.001 \\
(0.012)\end{array}$ & $\begin{array}{l}-0.007 \\
(0.011)\end{array}$ & $\begin{array}{l}0.018 \\
(0.026)\end{array}$ & $\begin{array}{l}0.004 \\
(0.015)\end{array}$ \\
\hline Brand: Kwik Trip & $\begin{array}{l}0.052^{* * *} \\
(0.011)\end{array}$ & $\begin{array}{l}0.052 * * * \\
(0.011)\end{array}$ & $\begin{array}{l}0.056^{* * *} \\
(0.013)\end{array}$ & $\begin{array}{l}0.054^{* * *} \\
(0.012)\end{array}$ & $\begin{array}{l}0.050 * * * \\
(0.010)\end{array}$ & $\begin{array}{l}0.071^{* * *} \\
(0.022)\end{array}$ & $\begin{array}{l}0.057^{* * *} \\
(0.014)\end{array}$ \\
\hline Brand: SuperAmerica & $\begin{array}{l}0.068^{* *} \\
(0.032)\end{array}$ & $\begin{array}{l}0.069 * * \\
(0.033)\end{array}$ & $\begin{array}{l}0.073^{* *} \\
(0.033)\end{array}$ & $\begin{array}{l}0.075^{* *} \\
(0.033)\end{array}$ & $\begin{array}{l}0.066^{* *} \\
(0.032)\end{array}$ & $\begin{array}{l}0.092^{* *} \\
(0.040)\end{array}$ & $\begin{array}{l}0.078^{* *} \\
(0.033)\end{array}$ \\
\hline
\end{tabular}




\begin{tabular}{lccccccc}
\hline & \multicolumn{7}{c}{ Dependent Variable: log of E85 price (\$/gal) } \\
\cline { 2 - 8 } & $\mathbf{( 1 )}$ & $\mathbf{( 2 )}$ & $\mathbf{( 3 )}$ & $\mathbf{( 4 )}$ & $\mathbf{( 5 )}$ & $\mathbf{( 6 )}$ & $\mathbf{( 7 )}$ \\
\hline Brand: Other & $0.057^{* *}$ & $0.057^{* *}$ & $0.061^{* *}$ & $0.063^{* *}$ & $0.054^{* *}$ & $0.077^{* *}$ & $0.066^{* *}$ \\
& $(0.027)$ & $(0.027)$ & $(0.028)$ & $(0.028)$ & $(0.027)$ & $(0.036)$ & $(0.028)$ \\
\hline County FE & $\mathrm{Y}$ & $\mathrm{Y}$ & $\mathrm{Y}$ & $\mathrm{Y}$ & $\mathrm{Y}$ & $\mathrm{Y}$ & $\mathrm{Y}$ \\
Month FE & $\mathrm{Y}$ & $\mathrm{Y}$ & $\mathrm{Y}$ & $\mathrm{Y}$ & $\mathrm{Y}$ & $\mathrm{Y}$ & $\mathrm{Y}$ \\
Observations & 2,133 & 2,133 & 2,133 & 2,133 & 2,133 & 2,133 & 2,133 \\
Adjusted R-squared & 0.857 & 0.857 & 0.857 & 0.857 & 0.857 & 0.858 & 0.857 \\
Residual Std. Error & 0.049 & 0.049 & 0.049 & 0.049 & 0.049 & 0.049 & 0.049 \\
\hline
\end{tabular}

Notes: $\mathrm{mi}=$ miles. $* \mathrm{p}<0.1 ; * * \mathrm{p}<0.05 ; * * * \mathrm{p}<0.01$. Standard errors clustered at the county level. Omitted bin is nearest station outside of 2 miles. Unbranded stations are the omitted brand category. 
Table A-13. Cross-Section Analysis: Minnesota Price Change (OPIS Data Only)

\begin{tabular}{|c|c|c|c|c|c|c|c|}
\hline & \multicolumn{7}{|c|}{ Dependent Variable: E85 price (\$/gal) } \\
\hline & (1) & $(2)$ & (3) & (4) & (5) & (6) & (7) \\
\hline Retail gasoline price (\$/gal) & $\begin{array}{l}0.369^{* * *} \\
(0.057)\end{array}$ & $\begin{array}{l}0.369^{* * *} \\
(0.057)\end{array}$ & $\begin{array}{l}0.367^{* * *} \\
(0.057)\end{array}$ & $\begin{array}{l}0.373^{* * *} \\
(0.053)\end{array}$ & $\begin{array}{l}0.370^{* * *} \\
(0.058)\end{array}$ & $\begin{array}{l}0.367^{* * *} \\
(0.057)\end{array}$ & $\begin{array}{l}0.374^{* * *} \\
(0.050)\end{array}$ \\
\hline Rack ethanol price (\$/gal) & $\begin{array}{l}0.187^{* * *} \\
(0.021)\end{array}$ & $\begin{array}{l}0.187^{* * *} \\
(0.021)\end{array}$ & $\begin{array}{l}0.187^{* * *} \\
(0.021)\end{array}$ & $\begin{array}{l}0.188^{* * *} \\
(0.021)\end{array}$ & $\begin{array}{l}0.187^{* * *} \\
(0.021)\end{array}$ & $\begin{array}{l}0.187^{* * *} \\
(0.021)\end{array}$ & $\begin{array}{l}0.188^{* * *} \\
(0.021)\end{array}$ \\
\hline No. stations w/i $0.1 \mathrm{mi}$ & $\begin{array}{l}-0.023^{* * *} \\
(0.009)\end{array}$ & & & & & & \\
\hline No. stations w/i $0.5 \mathrm{mi}$ & & $\begin{array}{l}-0.023^{* * *} \\
(0.009)\end{array}$ & & & & & \\
\hline No. stations w/i $1 \mathrm{mi}$ & & & $\begin{array}{l}-0.028^{*} \\
(0.015)\end{array}$ & & & & \\
\hline No. stations w/i 2 mi & & & & $\begin{array}{l}-0.017 \\
(0.011)\end{array}$ & & & \\
\hline No. stations w/i 3 mi & & & & & $\begin{array}{l}-0.005 \\
(0.005)\end{array}$ & & \\
\hline Dist. to nearest station (10 mi) & & & & & & $\begin{array}{l}0.071 \\
(0.052)\end{array}$ & \\
\hline Bin: $x \leq 0.1 \mathrm{mi}$ & & & & & & & $\begin{array}{l}-0.022 * * * \\
(0.007)\end{array}$ \\
\hline Bin: $0.1 \mathrm{mi}<x \leq 0.5 \mathrm{mi}$ & & & & & & & - \\
\hline Bin: $0.5 \mathrm{mi}<x \leq 1 \mathrm{mi}$ & & & & & & & $\begin{array}{l}-0.045^{* *} \\
(0.022)\end{array}$ \\
\hline Bin: $1 \mathrm{mi}<x \leq 2 \mathrm{mi}$ & & & & & & & $\begin{array}{l}-0.036^{*} \\
(0.021)\end{array}$ \\
\hline Dist. to terminal (10 mi) & $\begin{array}{l}-0.026^{*} \\
(0.015) \\
\end{array}$ & $\begin{array}{l}-0.026^{*} \\
(0.015) \\
\end{array}$ & $\begin{array}{l}-0.024^{* *} \\
(0.012)\end{array}$ & $\begin{array}{l}-0.031^{* *} \\
(0.014)\end{array}$ & $\begin{array}{l}-0.034^{* * *} \\
(0.012)\end{array}$ & $\begin{array}{l}-0.032^{* * *} \\
(0.012)\end{array}$ & $\begin{array}{l}-0.028^{* *} \\
(0.012)\end{array}$ \\
\hline Countv FE & $\mathrm{Y}$ & $\mathrm{Y}$ & $\mathrm{Y}$ & Y & $\mathrm{Y}$ & $\mathrm{Y}$ & Y \\
\hline Month FE & $\mathrm{Y}$ & $\mathrm{Y}$ & $\mathrm{Y}$ & $\mathrm{Y}$ & $\mathrm{Y}$ & $\mathrm{Y}$ & $\mathrm{Y}$ \\
\hline Observations & 1.884 & 1.884 & 1.884 & 1.884 & 1.884 & 1.884 & 1.884 \\
\hline Adiusted R-squared & 0.869 & 0.869 & 0.870 & 0.870 & 0.869 & 0.870 & 0.871 \\
\hline Residual Std. Error & 0.106 & 0.106 & 0.106 & 0.105 & 0.106 & 0.106 & 0.105 \\
\hline
\end{tabular}

Notes: $\mathrm{mi}=$ miles. ${ }^{*} \mathrm{p}<0.1 ;{ }^{* *} p<0.05 ;{ }^{* *} p<0.01$. Standard errors clustered at the county level. Omitted bin is nearest station outside of 2 miles. Insufficient variation to estimate bin " $0.1 \mathrm{mi}<x \leq 0.5 \mathrm{mi}$." 
Table A-14. Cross-Section Analysis: Minnesota Price Change with Brand Controls (OPIS Data Only)

\begin{tabular}{|c|c|c|c|c|c|c|c|}
\hline & \multicolumn{7}{|c|}{ Dependent Variable: E85 price (\$/gal) } \\
\hline & (1) & (2) & (3) & (4) & (5) & (6) & (7) \\
\hline Retail gasoline price (\$/gal) & $\begin{array}{l}0.399 * * * \\
(0.043)\end{array}$ & $\begin{array}{l}0.399 * * * \\
(0.043)\end{array}$ & $\begin{array}{l}0.398^{* * *} \\
(0.044)\end{array}$ & $\begin{array}{l}0.401^{* * *} \\
(0.044)\end{array}$ & $\begin{array}{l}0.401^{* * *} \\
(0.045)\end{array}$ & $\begin{array}{l}0.398^{* * *} \\
(0.044)\end{array}$ & $\begin{array}{l}0.398^{* * *} \\
(0.043)\end{array}$ \\
\hline Rack ethanol price (\$/gal) & $\begin{array}{l}0.192^{* * *} \\
(0.021)\end{array}$ & $\begin{array}{l}0.192^{* * *} \\
(0.021)\end{array}$ & $\begin{array}{l}0.192^{* * *} \\
(0.021)\end{array}$ & $\begin{array}{l}0.192^{* * *} \\
(0.021)\end{array}$ & $\begin{array}{l}0.192^{* * *} \\
(0.021)\end{array}$ & $\begin{array}{l}0.192^{* * *} \\
(0.021)\end{array}$ & $\begin{array}{l}0.192^{* * *} \\
(0.021)\end{array}$ \\
\hline No. stations w/i $0.1 \mathrm{mi}$ & $\begin{array}{l}-0.031^{* * *} \\
(0.006)\end{array}$ & & & & & & \\
\hline No. stations w/i $0.5 \mathrm{mi}$ & & $\begin{array}{l}-0.031^{* * *} \\
(0.006)\end{array}$ & & & & & \\
\hline No. stations w/i $1 \mathrm{mi}$ & & & $\begin{array}{l}-0.021 \\
(0.016)\end{array}$ & & & & \\
\hline No. stations w/i $2 \mathrm{mi}$ & & & & $\begin{array}{l}-0.010 \\
(0.008)\end{array}$ & & & \\
\hline No. stations w/i $3 \mathrm{mi}$ & & & & & $\begin{array}{l}-0.005 \\
(0.004)\end{array}$ & & \\
\hline Dist. to nearest station (10 mi) & & & & & & $\begin{array}{l}0.069^{* * *} \\
(0.024)\end{array}$ & \\
\hline Bin: $x \leq 0.1 \mathrm{mi}$ & & & & & & & $\begin{array}{l}-0.031^{* * *} \\
(0.006)\end{array}$ \\
\hline Bin: $0.1 \mathrm{mi}<x \leq 0.5 \mathrm{mi}$ & & & & & & & - \\
\hline Bin: $0.5 \mathrm{mi}<x \leq 1 \mathrm{mi}$ & & & & & & & $\begin{array}{l}-0.026 \\
(0.022)\end{array}$ \\
\hline Bin: $1 \mathrm{mi}<x \leq 2 \mathrm{mi}$ & & & & & & & $\begin{array}{l}-0.014 \\
(0.009)\end{array}$ \\
\hline Dist. to terminal (10 mi) & $\begin{array}{l}-0.013 \\
(0.010)\end{array}$ & $\begin{array}{l}-0.013 \\
(0.010)\end{array}$ & $\begin{array}{l}-0.012 \\
(0.011)\end{array}$ & $\begin{array}{l}-0.018^{*} \\
(0.010)\end{array}$ & $\begin{array}{l}-0.021^{* *} \\
(0.009)\end{array}$ & $\begin{array}{l}-0.018^{* * *} \\
(0.007)\end{array}$ & $\begin{array}{l}-0.013 \\
(0.010)\end{array}$ \\
\hline Brand: Freedom & $\begin{array}{l}0.064^{* * *} \\
(0.014)\end{array}$ & $\begin{array}{l}0.064^{* * *} \\
(0.014)\end{array}$ & $\begin{array}{l}0.076^{* * *} \\
(0.019)\end{array}$ & $\begin{array}{l}0.067^{* * *} \\
(0.011)\end{array}$ & $\begin{array}{l}0.072^{* * *} \\
(0.015)\end{array}$ & $\begin{array}{l}0.108^{* * *} \\
(0.018)\end{array}$ & $\begin{array}{l}0.076^{* * *} \\
(0.017)\end{array}$ \\
\hline Brand: Holiday & $\begin{array}{l}-0.005 \\
(0.015)\end{array}$ & $\begin{array}{l}-0.005 \\
(0.015)\end{array}$ & $\begin{array}{l}0.011 \\
(0.021)\end{array}$ & $\begin{array}{l}0.008 \\
(0.014)\end{array}$ & $\begin{array}{l}0.004 \\
(0.013)\end{array}$ & $\begin{array}{l}0.040 * * \\
(0.016)\end{array}$ & $\begin{array}{l}0.018 \\
(0.022)\end{array}$ \\
\hline Brand: Kwik Trip & $\begin{array}{l}0.139 * * * \\
(0.010)\end{array}$ & $\begin{array}{l}0.139 * * * \\
(0.010)\end{array}$ & $\begin{array}{l}0.149^{* * *} \\
(0.014)\end{array}$ & $\begin{array}{l}0.144^{* * *} \\
(0.009)\end{array}$ & $\begin{array}{l}0.146^{* * *} \\
(0.010)\end{array}$ & $\begin{array}{l}0.171^{* * *} \\
(0.012)\end{array}$ & $\begin{array}{l}0.150^{* * *} \\
(0.014)\end{array}$ \\
\hline
\end{tabular}




\begin{tabular}{lccccccccc}
\hline & \multicolumn{7}{c}{ Dependent Variable: E85 price (\$/gal) } \\
\cline { 2 - 9 } & $\mathbf{( 1 )}$ & & $\mathbf{( 2 )}$ & & $\mathbf{( 3 )}$ & $\mathbf{( 4 )}$ & $\mathbf{( 5 )}$ & $\mathbf{( 6 )}$ & $\mathbf{( 7 )}$ \\
\hline Countv FE & $\mathrm{Y}$ & $\mathrm{Y}$ & $\mathrm{Y}$ & $\mathrm{Y}$ & $\mathrm{Y}$ & $\mathrm{Y}$ & $\mathrm{Y}$ \\
Month FE & $\mathrm{Y}$ & $\mathrm{Y}$ & $\mathrm{Y}$ & $\mathrm{Y}$ & $\mathrm{Y}$ & $\mathrm{Y}$ & $\mathrm{Y}$ \\
Observations & 1.884 & 1.884 & 1.884 & 1.884 & 1.884 & 1.884 & 1.884 \\
Adiusted R-squared & 0.876 & 0.876 & 0.876 & 0.876 & 0.876 & 0.876 & 0.876 \\
Residual Std. Error & 0.103 & 0.103 & 0.103 & 0.103 & 0.103 & 0.103 & 0.103 \\
\hline
\end{tabular}

Notes: $\mathrm{mi}=$ miles. ${ }^{*} p<0.1 ;{ }^{* *} p<0.05 ;{ }^{* * *} p<0.01$. Standard errors clustered the county level. Omitted bin is nearest station outside of 2 miles. Insufficient variation to estimate bin " $0.1 \mathrm{mi}<x \leq 0.5 \mathrm{mi}$." Unbranded stations are the omitted brand category. 